Argonne

ANL-17/08

\title{
The Business Case for Fuel Cells: Delivering Sustainable Value
}

7th Edition

Argonne National Laboratory
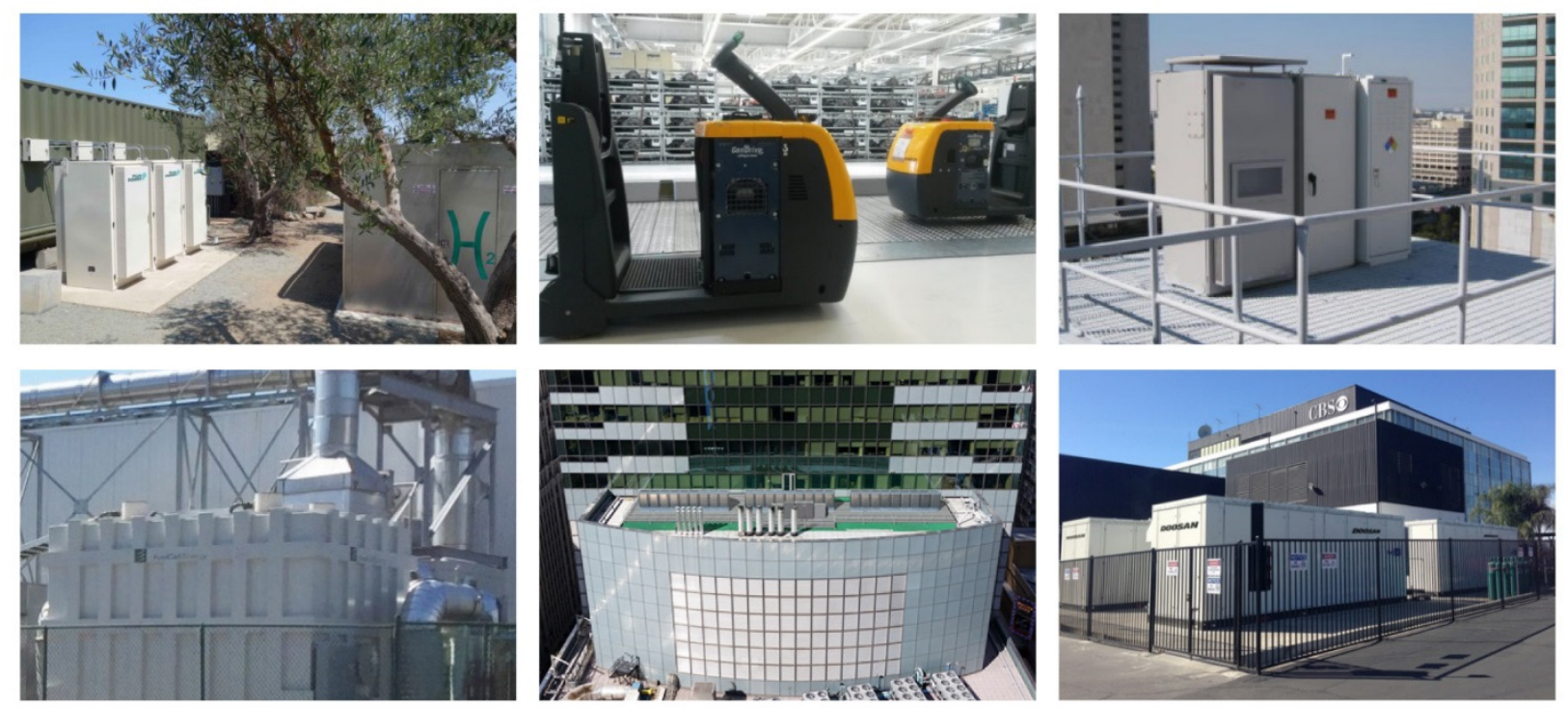
All images were approved for use by the relevant fuel cell manufacturer or customer. Photo sources for images in the report are listed in Appendix 2.

Top left: $\quad$ Plug Power GenSure units at Stone Edge Farm in Sonoma Valley, California. Photo Courtesy of Plug Power.

Top middle: Plug Power GenDrive fuel cells powering forklifts at a Volkswagen manufacturing facility in Kassel, Germany. Photo courtesy of Plug Power.

Bottom right: Altergy Freedom Power fuel cell units on a Florida rooftop. Photo courtesy of Altergy Systems.

Bottom left: FuelCell Energy systems at Pepperidge Farm. Photo courtesy of FuelCell Energy.

Bottom middle: Bloom Energy fuel cell system at Morgan Stanley headquarters in New York City, New York. Photo courtesy of Bloom Energy.

Bottom right: Doosan Fuel Cell America, Inc. units at CBS Studios. Photo courtesy of Doosan Fuel Cell America, Inc.

\author{
About Argonne National Laboratory \\ Argonne is a U.S. Department of Energy laboratory managed by UChicago Argonne, LLC \\ under contract DE-AC02-06CH11357. The Laboratory's main facility is outside Chicago, \\ at 9700 South Cass Avenue, Argonne, Illinois 60439. For information about Argonne \\ and its pioneering science and technology programs, see www.anl.gov.
}

\title{
DOCUMENT AVAILABILITY
}

Online Access: U.S. Department of Energy (DOE) reports produced after 1991 and a growing number of pre-1991 documents are available free via DOE's SciTech Connect (http://www.osti.gov/scitech/).

Reports not in digital format may be purchased by the public from the National Technical Information Service (NTIS):

U.S. Department of Commerce

National Technical Information Service

5301 Shawnee Road

Alexandria, VA 22312

www.ntis.gov

Phone: (800) 553-NTIS (6847) or (703) 605-6000

Fax: (703) 605-6900

Email: orders@ntis.gov

Reports not in digital format are available to DOE and DOE contractors from:

U.S. Department of Energy

Office of Scientific and Technical Information

P.O. Box 62

Oak Ridge, TN 37831-0062

\footnotetext{
Disclaimer

This report was prepared as an account of work sponsored by an agency of the United States Government. Neither the United States Government nor any agency thereof, nor UChicago Argonne, LLC, nor any of their employees or officers, makes any warranty, express or implied, or assumes any legal liability or responsibility for the accuracy, completeness, or usefulness of any information, apparatus, product, or process disclosed, or represents that its use would not infringe privately owned rights. Reference herein to any specific commercial product, process, or service by trade name, trademark, manufacturer, or otherwise, does not necessarily constitute or imply its endorsement, recommendation, or favoring by the United States Government or any agency thereof. The views and opinions of document authors expressed herein do not necessarily state or reflect those of the United States Government or any agency thereof, Argonne National Laboratory, or UChicago Argonne, LLC.
} 


\section{The Business Case for Fuel Cells: Delivering Sustainable Value}

\section{7th Edition}

by

Thomas G. Benjamin, Argonne National Laboratory

Jennifer Gangi, Fuel Cell and Hydrogen Energy Association

Sandra Curtin, Fuel Cell and Hydrogen Energy Association

June 2017 


\section{About This Report}

The report provides an overview of recent private sector fuel cell installations at U.S. businesses as of December 31, 2016. Based on the success of early stage research and development (R\&D) activities under U.S. Department of Energy (DOE) programs, including those at national laboratories, monitoring early private sector fuel cell installations can provide valuable feedback to guide further R\&D activities. Over the past few decades, hundreds of thousands of fuel cells have been installed around the world, for primary or backup power, as well as in various other applications including portable and emergency backup power. Fuel cells have also been deployed in other applications such as heat and electricity for homes and apartments, material handling, passenger vehicles, buses, and remote, off-grid sites. This list is by no means exhaustive.

Argonne National Laboratory (ANL) has supported the DOE's Fuel Cell Technologies Office (FCTO) in hydrogen and fuel cell technology evaluation and analysis for over two decades and has worked with the national trade association and fuel cell stakeholders for expertise in fuel cell technology. The information on applications and installations contained in this report was gathered from public sources and through personal contact with fuel cell manufacturers, customers and organizations.

\section{Authors and Acknowledgements}

This report was written and compiled for ANL by Sandra Curtin and Jennifer Gangi of the Fuel Cell and Hydrogen Energy Association (FCHEA) in Washington, D.C.

\section{Notice}

This report was supported by the U.S. DOE's FCTO within the Office of Energy Efficiency and Renewable Energy under contract 5F-30443 between FCHEA and UChicago Argonne LLC, as operator of Argonne National Laboratory for the DOE under Prime Contract No. DE-AC02-06CH11357. As such, this document was prepared in compliance with Section 515 of the Treasury and General Government Appropriations Act for Fiscal Year 2001 (Public Law 106-554) and information quality guidelines issued by DOE.

Neither the United States government, Argonne National Laboratory, FCHEA, nor any agency thereof, nor any of their employees, makes any warranty, express or implied, or assumes any legal liability or responsibility for the accuracy, completeness, or usefulness of any information, apparatus, product, or process disclosed, or represents that its use would not infringe privately owned rights. All product and company names are trademarks $\left(^{\mathrm{TM}}\right.$ ) or registered trademarks $\left({ }^{\circledR}\right)$, as indicated, of their respective owners. Use of these trademarks does not imply affiliation with or endorsement by the trademark owners. Reference herein to any specific commercial product, process, or service by trade name, trademark, manufacturer, or otherwise does not necessarily constitute or imply its endorsement, recommendation, or favoring by the United States government or any agency thereof. 


\section{Contents}

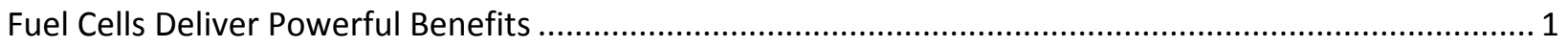

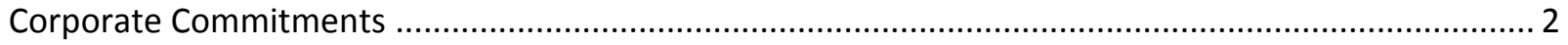

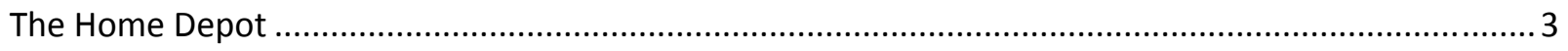

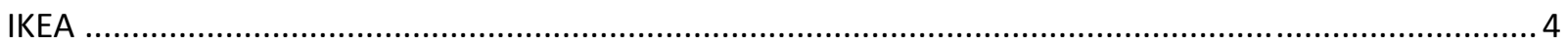

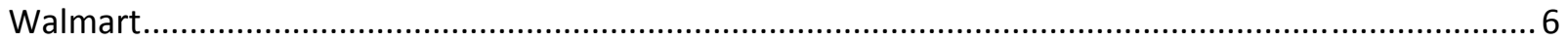

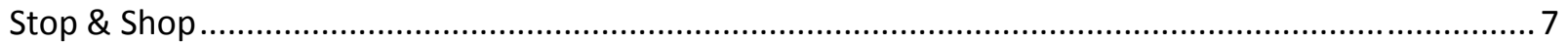

More Businesses and Services Relying on Fuel Cells ..................................................................... 7

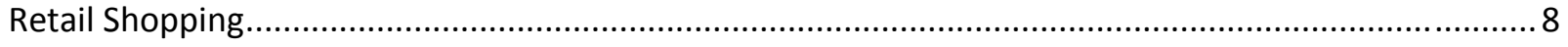

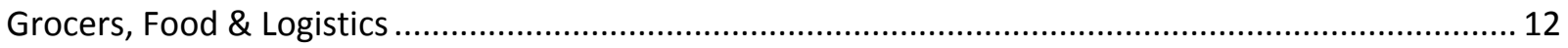

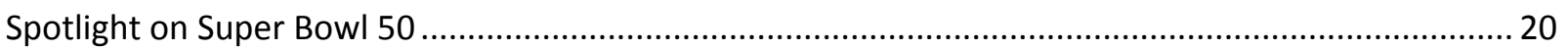

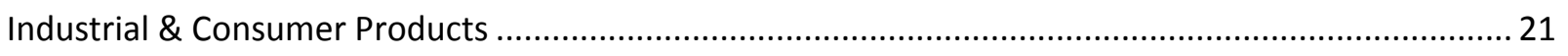

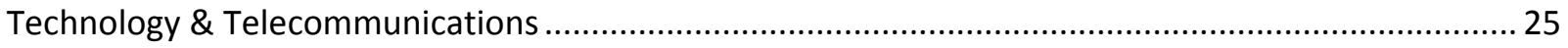

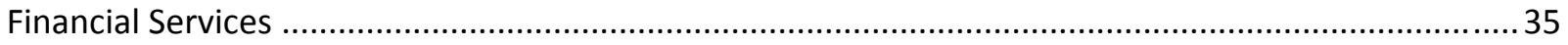

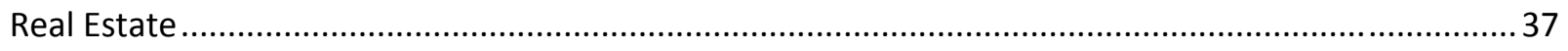

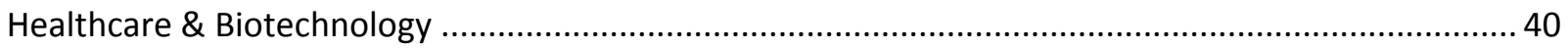

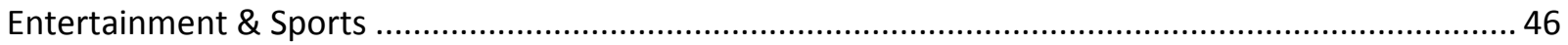

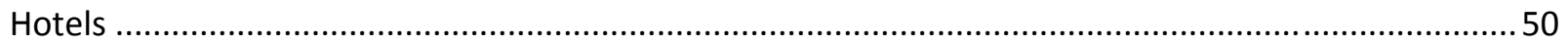

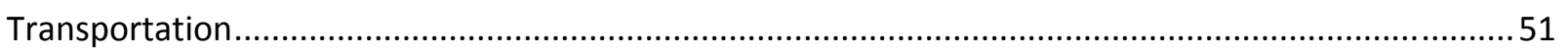

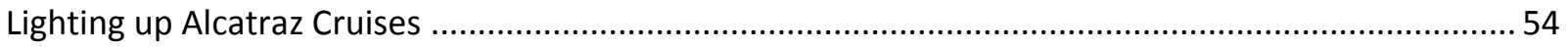

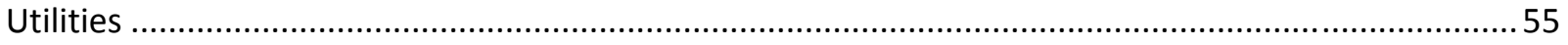

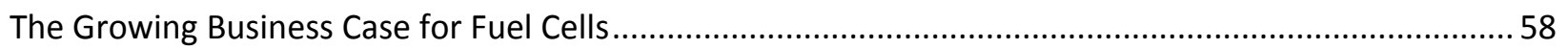

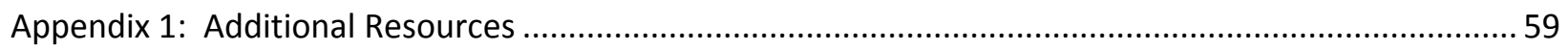

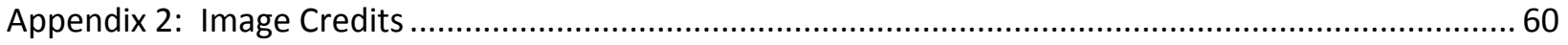

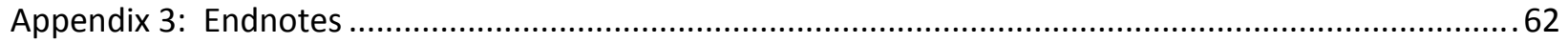




\section{Acronyms}

CHP Combined heat and power

$\mathrm{CO}_{2} \quad$ Carbon dioxide

DOE U.S. Department of Energy

FCV Fuel cell vehicle

kW Kilowatt

kWh Kilowatt-hour

lbs. Pounds

MHE Material handling equipment

MW Megawatt

sq.-ft. Square feet 


\section{Fuel Cells Deliver Powerful Benefits}

The business case for fuel cells is growing. With the industry rapidly emerging as a multibillion dollar market opportunity, the United States is staking a leadership role in technology development, manufacturing, and economic impact. A main reason for this success is the increasing investment by the private sector and business community.

While the government, primarily through the U.S. Department of Energy, has focused on early stage research and development,

\section{Highlights since last report}

- Home Depot now country's largest stationary fuel cell customer, with more than 140 sites

- IKEA installing fuel cells at 4 more stores in California and one in Connecticut

- eBay adding 3.75 MW to its Utah data center, bringing it to $\sim 10 \mathrm{MW}$

- More than 15,000 fuel cell-forklifts in operation or on order industry has been successfully commercializing and deploying cutting edge technologies in fuel cells and hydrogen that are now demonstrating tangible benefits.

Today, fuel cells are utilizing domestically produced natural gas to power to retail stores, data centers, production sites and other company facilities, greatly reducing emissions and doing so at a cost that can be competitive with the local electric grid in some states. ${ }^{1}{ }^{2}$ By producing power onsite, facilities can continue their essential operations, even when grid power goes down.

Fuel cells are also competing in the material handling market, with companies finding value in improved operational efficiency and cost savings using fuel cells in forklifts and other vehicles over battery units -

\section{About Fuel Cells}

A fuel cell generates electricity using an electrochemical reaction, not combustion, and, depending on the fuel source, produces zero or near-zero polluting emissions. Fuel cells offer a unique combination of proven benefits that make them ideally suited for a number of applications.

\section{Benefits for Stationary Applications}

- Can be primary or backup power source

- Operate in tandem or independent of electric grid

- High efficiency

- Low to zero emissions

- Fuel flexible (conventional or renewable fuels)

- Rugged and quiet

- Operate in water balance

- Modular and scalable
Benefits for Material Handling Equipment

- Zero emissions

- Long runtime

- Minutes to refuel

- Constant power (no voltage sag)

- Cold storage operation

- Eliminates need for battery charging room

- Increased worker productivity

- Lower operational costs 
eliminating the need for, and space dedicated to, battery charging and swapping. Fuel cells also allow for quicker refueling, which saves time, and full-power operation throughout the shift, without any voltage sag or challenges when operating in refrigerated warehouse environments.

In addition, telecommunications companies worldwide are turning to fuel cells to provide reliable primary or backup power and longer run times, while simultaneously benefitting from lower emissions. The reliability of fuel cells and freedom from the need for daily refueling at remote locations makes this a competitive technology in this application.

There are many reasons why companies choose fuel cells for stationary and motive power applications. The long list of benefits are outlined above and discussed at length in previous editions of this report, continue to make this technology an attractive option for new customers, as well as for companies choosing to expand their portfolio to dozens, hundreds, and even thousands of fuel cells. Fuel cells enable customers to attain not only environmental benefits, but also economic, operational, and other savings, as well.

\section{Corporate Commitments}

Corporate environmental goals are not just internalized within company walls. Many corporations are joining collaborative initiatives to publicly hold themselves more accountable. These include the Science Based Targets Initiative ${ }^{3}$, where companies pledge to adopt targets in line with the science on how to keep global warming below two degrees. There are now more than 170 corporations committed, including fuel cell users Coca-Cola, Procter \& Gamble, Walmart, Kellogg Company, Pfizer, and Carrefour, as well as automotive companies BMW, Honda, Daimler, Toyota, and Nissan, most of which have fuel cell forklifts deployed at manufacturing facilities, and all developing fuel cell light duty vehicles.

Another global initiative, the Climate Group's RE1004, includes influential businesses committed to transitioning to $100 \%$ renewable electricity, including biomass and biogas, geothermal, solar, water and wind - either sourced from the market or self-produced. The $100 \%$ renewable energy goal can be achieved by producing power either on or off-site at its facilities, or from procuring power via contracts with utilities, Power Purchase Agreements (PPAs) or renewable electricity certificates.

Many of the companies involved in RE100 operate fuel cells, including ones fueled by biogas, in some capacity, including: IKEA, Adobe, Apple, Bank of America, Equinix, Google, Johnson \& Johnson, CocaCola, BMW, GM, Procter \& Gamble, Walmart, as well as international users, La Poste, Marks \& Spencer, Colruyt Group, and Tata Motors.

The Climate Group estimates that, when all of its participating companies are operating with 100\% renewable energy, they will create demand for 90.1 terrawatt hours of renewable electricity, saving around 56 mega-tonnes of $\mathrm{CO}_{2}$ annually. 
There is also the Renewable Energy Buyers Alliance (REBA) ${ }^{5}$, formed by four non-governmental organizations to empower multinational companies to deploy renewable energy in the United States, with the goal of 60 gigawatts by 2025. REBA includes fuel cell users Adobe, BD, eBay, Equinix, FedEx, GM, Honda, IBM, Johnson \& Johnson, Kaiser Permanente, Marriott, Microsoft, Owens Corning, Sprint, Time Warner Cable, Whole Foods, and Yahoo!.

According to the Business Council for Sustainable Energy's 2016 Sustainable Energy in America Factbook $^{6}$, corporations, including fuel cell users Walmart, Johnson \& Johnson, Google and others, have doubled their investment in cleaner energy over the past two consecutive years.

The list of customers continues to grow, and since the last Business Case report, there have been some real standouts in the corporate world, becoming champion fuel cell advocates by purchasing, installing and deploying fuel cells in different applications, at multiple facilities around the country.

\section{The Home Depot}

Since our last report, The Home Depot has emerged as the leading corporate customer of stationary fuel cells, installing 200-kilowatt (kW) systems at stores in California, Connecticut and New York. The Home Depot began installing fuel cells in 2014 and, by late 2016 , is using fuel cells to generate power at 140 of its U.S. retail locations. ${ }^{7}$

Although the Home Depot has already deployed about 28 megawatts (MW) of fuel cell power generation, it isn't done yet - the company intends to add fuel cells to more stores for a total of 170 retail sites operating fuel cell for power generation. ${ }^{8}$

The Home Depot reports that the fuel cells provide electricity at a lower cost than the electric grid and, Bloom Energy Cbioom_Enegy : Jun 24 Bloom is proud to power $10 \%$ of Home Depot Stores \#powerofthehomedepot fortune.com/2016/06/24/app when stores have low power needs, it can send energy back to the grid. ${ }^{9}$

Carol Tome, The Home Depot's Chief Financial Officer, said "We look at the value of fuel cells in two ways. First, productivity - where we have the fuel cells installed, we see that our electricity costs are 15 to 20 percent less than they would be if we bought off the grid, so that's a good thing. And then, sustainability, because the fuel cells take natural gas and convert it to electricity without combustion, we see lower levels of carbon dioxide emissions. In fact, since 2014, our carbon dioxide emissions have been reduced by 50 million pounds. That's equivalent to removing 4800 cars off the roads and we're thrilled." ${ }^{10}$ 
Other benefits include huge water savings - each $200 \mathrm{~kW}$ fuel cell system saves 31 million gallons of water annually.

Craig D'Arcy, the Home Depot's director of Energy Management stated, "Perhaps the biggest driver that made fuel cells the right fit for the stores we've done so far is that they eliminate the concern over aging roofs. A solar install requires that the roof stay in place for at least 15 years, otherwise you significantly erode the financial benefit by incurring costs to remove and reinstall the solar system after the roof has been replaced." ${ }^{\prime 1}$

The Home Depot is also investing in fuel cells for material handling. In the last report, we detailed the Troy Township, Ohio, location, where the company deployed more than 175 fuel cell-powered forklifts are operating in its new 1.6 million-sq.-ft. distribution center. The Home Depot is now set to introduce another fleet of fuel cell forklifts at a Savannah, Georgia, distribution center. ${ }^{12}$

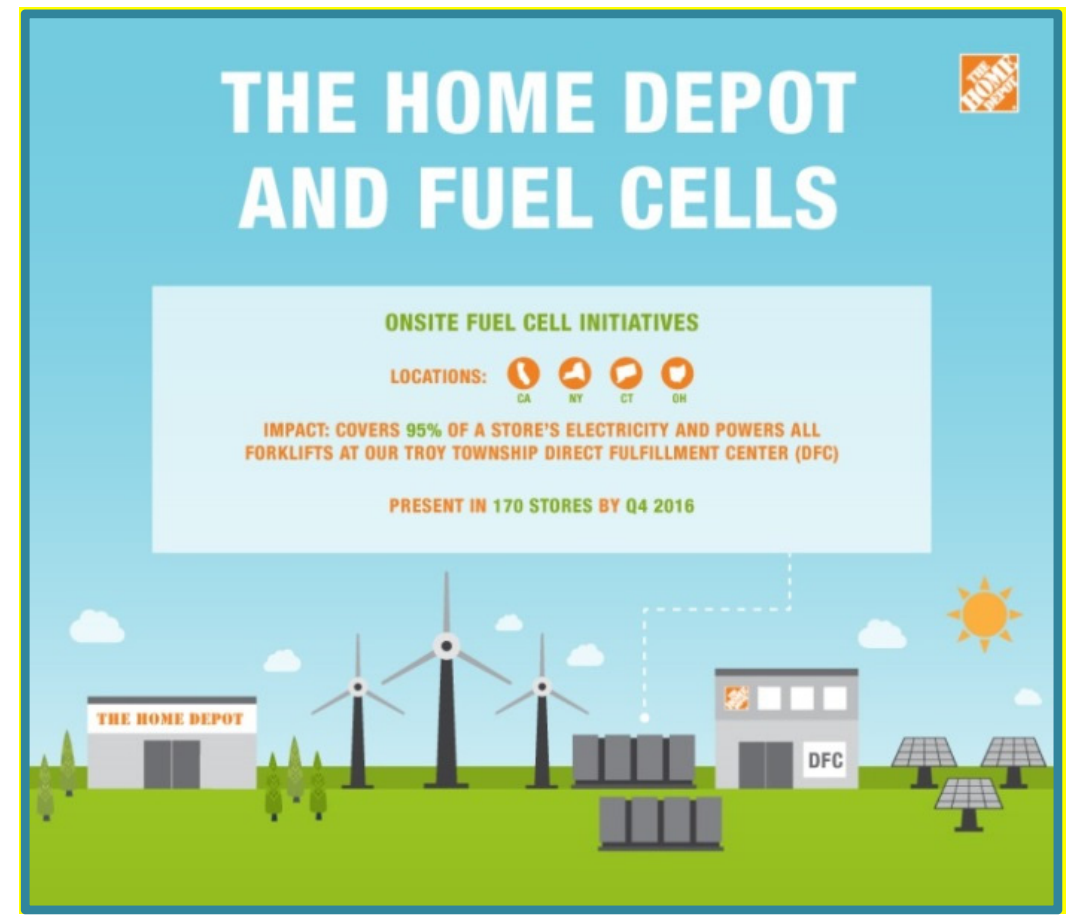

\section{IKEA}

Swedish furniture retailer IKEA expanded its fuel cell investment in 2016 by announcing it is adding fuel cells at four more California stores (see chart, next page) and one in New Haven, Connecticut. This will bring IKEA's total fuel cell fleet, including the 300-kW fuel cell installed in 2015 at its Emeryville, California, store, to more than $1.5 \mathrm{MW}$ of power. 
Christof Stein, IKEA's New Haven store manager, says that, "similar to our rooftop solar array, this fuel cell system will greatly reduce our carbon footprint and the store's reliance on the power grid as well as contribute to our vision of creating a better everyday life for the many."13

IKEA's history with fuel cells goes back even further, more than a decade, when the company partnered with Opel, a subsidiary of General Motors, to demonstrate the Open Zafira fuel cell vehicle in Berlin, Germany, in 2005. In 2010, IKEA tested the fourth generation of the Zafira.

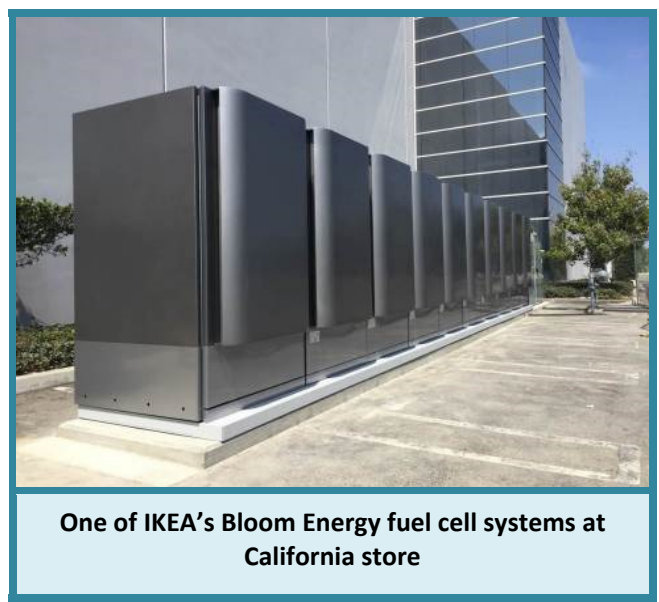

And in 2014, IKEA deployed a fleet of 20 forklift trucks at its distribution center in Saint-QuentinFallavier, France. The site also features a hydrogen station from Air Liquide to refuel the forklifts.

IKEA U.S. President Lars Petersson also says that, "fuel cells represent another way we can contribute to our goal of generating renewable energy equal to the amount of power we consume worldwide."14

\begin{tabular}{|c|c|c|c|}
\hline \multicolumn{4}{|c|}{ Details on IKEA's recent fuel cell announcements ${ }^{15}$} \\
\hline $\begin{array}{l}\text { Retail Store } \\
\text { Locations }\end{array}$ & Fuel Cells & $\begin{array}{l}\text { Anticipated Annual } \\
\text { Electricity } \\
\text { Production }\end{array}$ & $\begin{array}{l}\text { Emissions } \\
\text { Reduction } \\
\text { Equivalent }\end{array}$ \\
\hline $\begin{array}{l}\text { New Haven, } \\
\text { Connecticut }\end{array}$ & $\begin{array}{l}\text { 250-kW Bloom Energy Server. } \\
\text { The store's } 940.8-k W \text { solar array, } \\
\text { combined with the fuel cell, will } \\
\text { generate a majority of the store's } \\
\text { energy onsite. }\end{array}$ & $\begin{array}{l}\text { 2,081,376 kilowatt } \\
\text { hours ( } \mathrm{kWh} \text { ) }\end{array}$ & $\begin{array}{l}1,218 \text { tons of carbon } \\
\text { dioxide }\left(\mathrm{CO}_{2}\right)\end{array}$ \\
\hline $\begin{array}{l}\text { Costa Mesa, } \\
\text { California (installed), } \\
\text { and East Palo Alto, } \\
\text { California }\end{array}$ & 300-kW Bloom Energy Servers & $2,497,651 \mathrm{kWh}$ & 1,315 tons of $\mathrm{CO}_{2}$ \\
\hline $\begin{array}{l}\text { Covina, California } \\
\text { (installed), and San } \\
\text { Diego, California }\end{array}$ & 200-kW Bloom Energy Servers & $1,665,101 \mathrm{kWh}$ & 877 tons of $\mathrm{CO}_{2}$ \\
\hline
\end{tabular}




\section{Walmart}

Walmart has a goal to be supplied $100 \%$ by renewable energy. The company's efforts to meet this goal include the use of fuel cells both for onsite power generation and power for forklifts operating in the company's distribution centers.

In 2016 alone, Walmart installed 4.8 MW of Bloom Energy fuel cells to provide onsite power generation at seventeen of its California retail

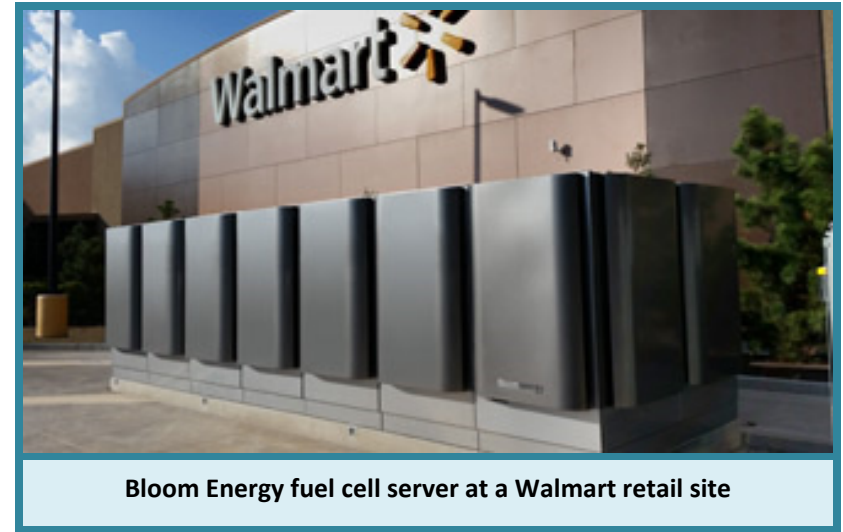
stores. This builds on Walmart's 2015 fuel cell installations, which include a total $1 \mathrm{MW}$ of fuel cell power generation in California (five retail stores), $400 \mathrm{~kW}$ in Connecticut (two retail stores), and a 250-kW fuel cell system supplying power at a New Jersey store.

In total, Walmart has installed fuel cells at more than 60 of its retail sites in California, Connecticut, and New Jersey, to provide $40-60 \%$ of the electricity needed by these facilities. ${ }^{16,17}$ When grid power goes down, these fuel cells are capable of supplying power to keep a store's refrigeration equipment, lighting, and cash registers in operation, preventing food spoilage and allowing a store to continue serving customers during weather-related and other outages. ${ }^{18}$ Walmart also reports that its fuel cells supply energy at prices lower than the cost of energy from local utilities. ${ }^{19}$

Walmart also uses Plug Power GenDrive fuel cells to power to forklifts at 19 of its North American distribution centers, including locations in Illinois, Indiana, Minnesota, New York, Ohio, Pennsylvania, Texas, and in Alberta and Ontario, Canada. In aggregate, the company operates more than 3,000 fuel cell-powered forklifts at its sites, along with the hydrogen fueling infrastructure to support these deployments.

Walmart states in its 2016 Global Sustainability Report that it is committed to

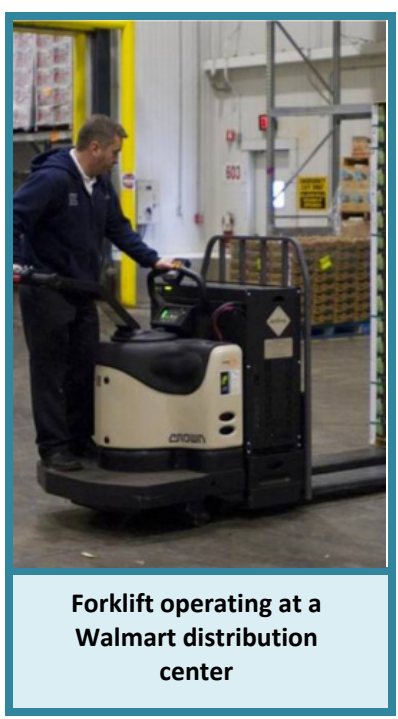
expanding its development of off- and onsite power from fuel cells, solar, wind, and other technologies in an effort to meet its goal of procuring 7 billion kWh of renewable energy generation by the end of 2020. ${ }^{20}$ 


\section{Stop \& Shop}

Northeast grocery chain Stop \& Shop, and its parent company Ahold, already uses fuel cells at three of its grocery stores to generate power onsite: two in New York - Peekskill (200-kW Bloom Energy Server, installed in 2015) and Mt. Vernon (250-kW Bloom Energy Server, installed in 2014), and a store in Torrington, Connecticut (400-kW Doosan Fuel Cell America system, installed in 2011).

The company also operates gas stations at several of its retail sites and has agreed to host a hydrogen refueling pump at its Mansfield, Massachusetts, grocery store. The proposed hydrogen station is one of 12 hydrogen stations in development by Toyota and Air Liquide to support the expansion of fuel cell vehicles into the northeast U.S., and recently received permit approval by the town's zoning board. ${ }^{21}$ The hydrogen supplied by Air Liquide will be produced off-site and delivered to the station, which is anticipated to be operable in $2017 .^{22}$

\section{More Businesses and Services Relying on Fuel Cells}

These select companies are just the tip of the technology iceberg. What follows is a chart that highlights businesses and services customers use and frequent every day, or that work behind the scenes to ensure everyone is connected and communicating. This list is not exhaustive, but shows that some of the world's leading companies, ones people trust with some of the most important facets of their lives, trust fuel cells - in some cases, powering entire facilities without grid connection, relying on fuel cells, in conjunction with renewables, to fully support operations.

The chart is divided into different market sectors and provides an update on any savings and progress since our last report, including new customers. This includes Retail Shopping; Grocers, Food \& Logistics; Industrial \& Consumer Products; Technology \& Telecommunications; Financial Services; Real Estate; Healthcare \& Biotechnology; Entertainment \& Sports; Hotels; Transportation; and Utilities. The update section in the chart also includes new or unreported information discovered through research and discussions with fuel cell manufacturers, fuel providers, and customers. 


\section{Retail Shopping}

Retail chains are taking advantage of fuel cells for power for their stores and material handling equipment (MHE) in their warehouses. Two of the leading fuel cell customers, Home Depot and Walmart, have more than 200 stores and 3,500 forklifts utilizing fuel cells collectively.

Onsite fuel cells can provide primary power, backup power and combined heat and power (CHP) to retail sites and warehouses. Since the systems can operate independently from the power grid, they can supply power without disruption due to grid failure or blackouts. The fuel cell's excess heat can also be captured to provide hot water or space heating, increasing the fuel cell's efficiency.

The benefits of converting material handling fleets to fuel cells are many, outlined in the introduction as well as in previous reports. For the retail sector, the main advantage of using fuel cells for MHE could arguably be the elimination of battery storage, changing, and charging areas, allowing that space to be regained and utilized to hold more products.

\begin{tabular}{|c|c|c|}
\hline \multicolumn{3}{|c|}{$\begin{array}{l}\text { Examples of Companies that Rely on Fuel Cells: } \\
\qquad \text { Retail Shopping }\end{array}$} \\
\hline COMPANY & BACKGROUND & UPDATE \\
\hline CVS & $\begin{array}{l}\text { CVS operates more than } 65 \\
\text { forklifts powered by Plug Power } \\
\text { fuel cells at its LEED-certified } \\
\text { distribution center in Waverly, } \\
\text { New York, which opened in } 2011 .\end{array}$ & $\begin{array}{l}\text { The distribution center takes } \\
\text { advantage of the fuel cells' } \\
\text { water byproduct - repurposing } \\
\text { the water for use in cleaning } \\
\text { processes, rather than } \\
\text { discharging it. }{ }^{23}\end{array}$ \\
\hline The Home Depot & $\begin{array}{l}\text { The Home Depot began installing } \\
200-k W \text { Bloom Energy Servers in } \\
2014 \text { and now has fuel cells at } \\
\text { more than } 140 \text { retail stores in } \\
\text { California, Connecticut and New } \\
\text { York. } \\
\text { The Home Depot also operates } \\
\text { more than } 175 \text { fuel cell-powered } \\
\text { forklifts at an Ohio distribution } \\
\text { center. }\end{array}$ & $\begin{array}{l}\text { The Home Depot plans to add a } \\
\text { fleet of fuel cell-forklifts at its } \\
\text { Savannah, Georgia, distribution } \\
\text { center as well as increasing the } \\
\text { number of store installations to } \\
170 \text { by the end of } 2016 .^{24} \\
\text { Since } 2014 \text {, The Home Depot } \\
\text { reported that its stationary fuel } \\
\text { cell fleet has reduced its carbon } \\
\text { dioxide emissions by } 50 \text { million } \\
\text { pounds. }{ }^{25}\end{array}$ \\
\hline
\end{tabular}




\begin{tabular}{|c|c|c|}
\hline \multicolumn{3}{|c|}{$\begin{array}{l}\text { Examples of Companies that Rely on Fuel Cells: } \\
\qquad \text { Retail Shopping }\end{array}$} \\
\hline COMPANY & BACKGROUND & UPDATE \\
\hline IKEA & $\begin{array}{l}\text { IKEA installed a 300-kW fuel cell } \\
\text { from Bloom Energy at a store in } \\
\text { Emeryville, California, in } 2015 . \\
\text { IKEA also operates a fleet of fuel } \\
\text { cell forklifts at a distribution } \\
\text { center in Saint-Quentin-Fallavier, } \\
\text { France. } \\
\text { In addition, IKEA has tested fuel } \\
\text { cell vehicles in Germany, including } \\
\text { both an Opel (GM) HydroGen3 } \\
\text { and a HydroGen4. }\end{array}$ & $\begin{array}{l}\text { IKEA's Emeryville fuel cell } \\
\text { reduces } \mathrm{CO}_{2} \text { emissions by an } \\
\text { estimated } 823,000 \text { Ibs. } \\
\text { annually. }{ }^{26} \\
\text { In July 2016, IKEA announced } \\
\text { plans for Bloom Energy fuel cells } \\
\text { at four additional California } \\
\text { stores - Costa Mesa, Covina, } \\
\text { East Palo Alto, and San Diego. }{ }^{27} \\
\text { In August 2016, IKEA also stated } \\
\text { that its first east coast Bloom } \\
\text { Energy fuel cell system will be } \\
\text { located at its New Haven, } \\
\text { Connecticut, store. When } \\
\text { completed, IKEA will have a } \\
\text { portfolio of more than } 1.5 \mathrm{MW} \\
\text { of stationary fuel cells. }{ }^{28}\end{array}$ \\
\hline Macy's & $\begin{array}{l}\text { In 2013, Macy's installed a } 600-k W \\
\text { Bloom Energy Server fuel cell } \\
\text { system to provide baseload } 24 \times 7 \\
\text { power to its Cheshire, } \\
\text { Connecticut, online fulfillment } \\
\text { center. }\end{array}$ & $\begin{array}{l}\text { Macy's is tracking }{ }^{29} \text { its fuel cell's } \\
\text { energy generation and the } \\
\text { emissions reductions it is helping } \\
\text { to achieve. The company } \\
\text { reports that in one month } \\
\text { (Mar.-Apr. 2016), the fuel cell } \\
\text { generated more than } \\
17,560,000 \text { kilowatts per hour } \\
\text { and avoided more than } \\
9,800,000 \text { lbs. of } \mathrm{CO}_{2} \text { emissions. }\end{array}$ \\
\hline
\end{tabular}




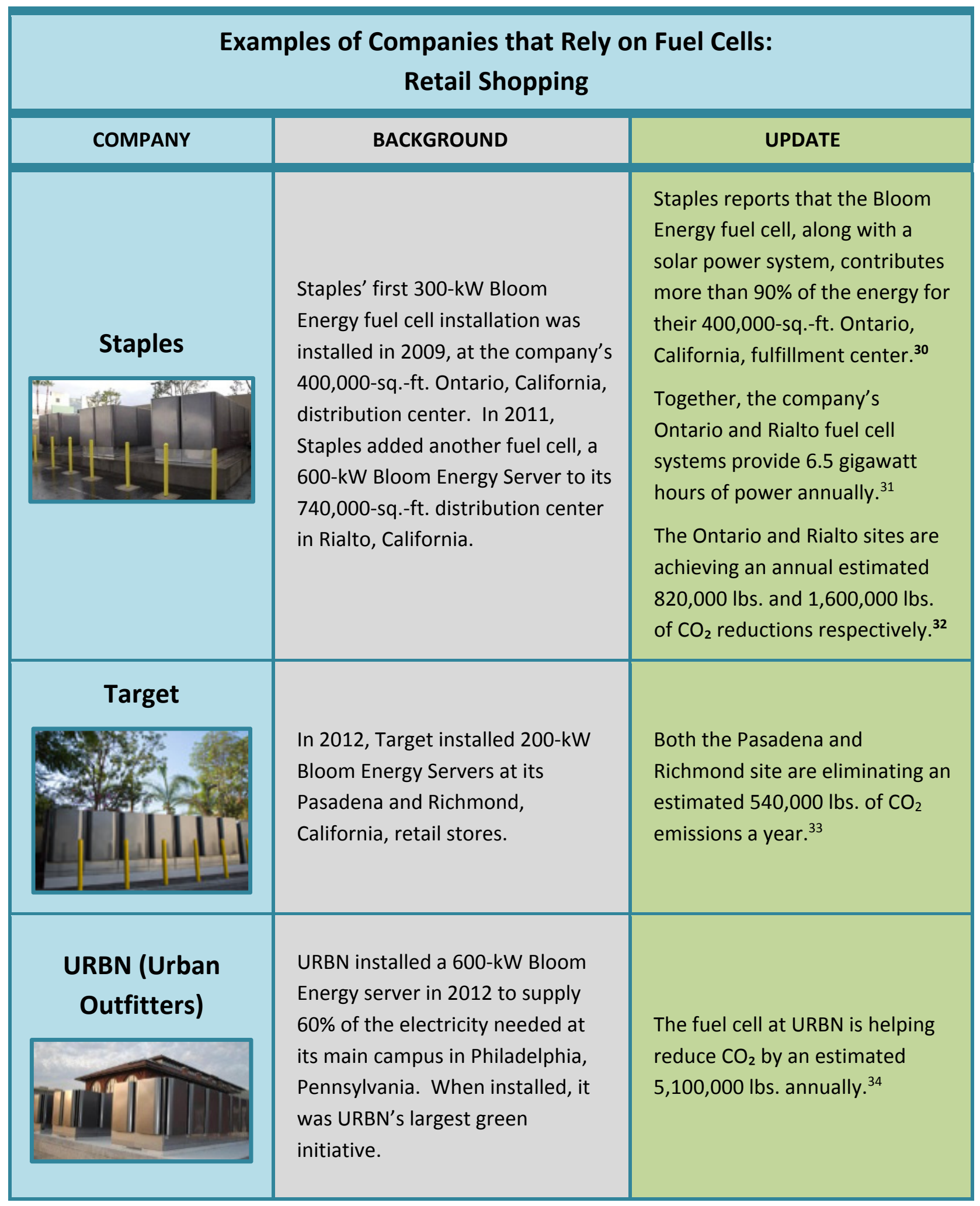




\begin{tabular}{|c|c|c|}
\hline \multicolumn{3}{|c|}{$\begin{array}{l}\text { Examples of Companies that Rely on Fuel Cells: } \\
\qquad \text { Retail Shopping }\end{array}$} \\
\hline COMPANY & BACKGROUND & UPDATE \\
\hline 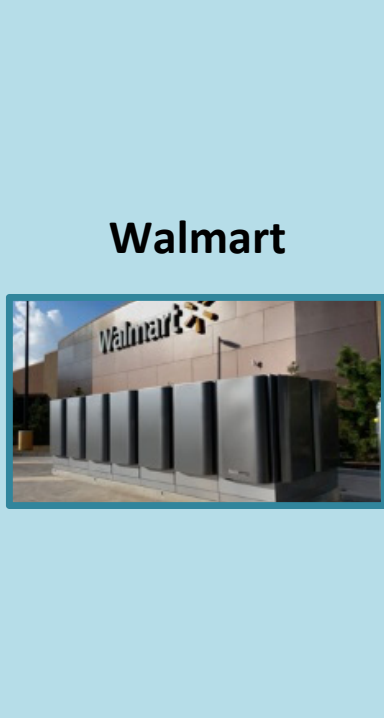 & $\begin{array}{l}\text { Walmart is the largest user of fuel } \\
\text { cell-powered forklifts, operating } \\
\text { more than 3,000 units that are } \\
\text { powered by Plug Power GenDrive } \\
\text { fuel cells. They are located at } \\
19 \text { distribution centers in North } \\
\text { America, including Illinois, } \\
\text { Minnesota, New York, Ohio, } \\
\text { Pennsylvania, Texas, and Canada. } \\
\text { Walmart also uses stationary fuel } \\
\text { cells to provide power to retail } \\
\text { stores in California, Connecticut, } \\
\text { and New Jersey. }\end{array}$ & $\begin{array}{l}\text { Walmart is committed to be } \\
100 \% \text { renewable and } \\
\text { sustainable, with an interim goal } \\
\text { to produce or procure } 7 \text { billion } \\
\text { kWh of renewable energy by the } \\
\text { end of } 2020 . \text { Walmart's Vice } \\
\text { President of Energy, Mark } \\
\text { Vanderhelm, has stated that the } \\
\text { main focus currently is solar, } \\
\text { and that wind and fuel cell } \\
\text { storage are next on the list. }\end{array}$ \\
\hline Williams-Sonoma & $\begin{array}{l}\text { William-Sonoma installed a 600- } \\
\text { kW Bloom Energy Server in } 2012 \\
\text { to provide power to its Rocklin, } \\
\text { California, data center. }\end{array}$ & $\begin{array}{l}\text { Williams-Sonoma's fuel cell } \\
\text { system is reducing its } \mathrm{CO}_{2} \\
\text { emissions by an estimated } \\
1,600,000 \text { lbs. a year. }{ }^{36}\end{array}$ \\
\hline & \multicolumn{2}{|c|}{ BACKGROUND } \\
\hline $\begin{array}{l}\text { Additional } \\
\text { Companies }\end{array}$ & \multicolumn{2}{|c|}{$\begin{array}{l}\text { Ace Hardware deployed lift trucks outfitted with } 80 \text { Plug Power } \\
\text { GenDrive fuel cells at a new Retail Support Center in Wilmer, Texas, in } \\
\text { 2013. In 2014, the company added fuel cell-powered reach trucks and } \\
\text { pallet jacks, plus a floor scrubber at a Retail Support Center in West } \\
\text { Jefferson, Ohio. Together, the two sites have more than } 130 \text { hydrogen- } \\
\text { powered vehicles in operation. Both sites use Nuvera's PowerTap }{ }^{\text {TM }} \\
\text { on-site hydrogen generation and fueling system. } \\
\text { Lowe's deployed more than } 200 \text { lift trucks equipped with Plug Power } \\
\text { fuel cells at its Adairsville, Georgia, regional distribution center in } 2012 . \\
\text { Earlier, the company conducted pilot projects of fuel cell MHE at } \\
\text { regional distribution centers in California and Connecticut. }\end{array}$} \\
\hline
\end{tabular}




\section{Grocers, Food \& Logistics}

From supermarkets to the companies that provide the goods to stock them, fuel cells are becoming a 'greenlight' special in the grocery, food and beverage industry.

Fuel cells can provide uninterrupted power, even when the grid is down, while helping grocery stores and food packaging facilities reduce overall emissions. The heat fuel cells generate as a byproduct can be used for space heating, hot water, or run through an absorption chiller for air conditioning or refrigeration, providing increased efficiency for stores that have to keep food cold or fresh.

Fuel cell-powered forklifts are currently in operation at logistics facilities, distribution centers, and grocery warehouses around the country, replacing incumbent battery-powered and combustion vehicles due to their advantages of longer runtime, faster refueling, higher efficiency, and constant power, especially in freezers and cold storage facilites.

\begin{tabular}{|c|c|c|}
\hline \multicolumn{3}{|c|}{$\begin{array}{l}\text { Examples of Companies that Rely on Fuel Cells: } \\
\text { Grocers, Food \& Logistics }\end{array}$} \\
\hline COMPANY & BACKGROUND & UPDATE \\
\hline Americold & $\begin{array}{l}\text { Cold storage company } \\
\text { Americold uses a } 600-\mathrm{kW} \\
\text { Bloom Energy server at its } \\
\text { Salinas, California, facility. }\end{array}$ & $\begin{array}{l}\text { Americold reports the fuel cell } \\
\text { generates more than } 600,000 \\
\text { kWh annually. }{ }^{37} \text { It also saves an } \\
\text { estimated } 1,600,000 \text { lbs. of } \mathrm{CO}_{2} \\
\text { emissions per year. }{ }^{38}\end{array}$ \\
\hline Coca-Cola & $\begin{array}{l}\text { Coca-Cola operates: } \\
\text { - A 1-MW Bloom Energy fuel } \\
\text { cell at its American Canyon, } \\
\text { California, bottling facility. } \\
\text { - A 500-kW Bloom Energy fuel } \\
\text { cell at a Dinuba, California, } \\
\text { Odwalla production facility. } \\
\text { - Two Doosan Fuel Cell America } \\
\text { PureCell units (800 kW) at its } \\
\text { Elmsford, New York plant. } \\
\text { - An 800-kW Doosan fuel cell } \\
\text { system at its East Hartford, } \\
\text { Connecticut, bottling facility. }\end{array}$ & $\begin{array}{l}\text { The fuel cells at Coca-Cola's } \\
\text { California facility eliminate an } \\
\text { estimated } 2,700,000 \text { lbs. of } \mathrm{CO}_{2} \\
\text { annually, while the California } \\
\text { Odwalla production facility } \\
\text { project achieves an estimated } \\
1,300,000 \text { lbs. of } \mathrm{CO}_{2} \text { reductions } \\
\text { a year. }{ }^{39}\end{array}$ \\
\hline
\end{tabular}




\begin{tabular}{|c|c|c|}
\hline \multicolumn{3}{|c|}{$\begin{array}{l}\text { Examples of Companies that Rely on Fuel Cells: } \\
\text { Grocers, Food \& Logistics }\end{array}$} \\
\hline COMPANY & BACKGROUND & UPDATE \\
\hline Coca-Cola cont'd & $\begin{array}{l}\text { In 2012, Coca-Cola deployed a } \\
\text { fleet of } 56 \text { fuel cell forklifts at a } \\
\text { California bottling plant and, in } \\
2014,50 \text { fuel cell-powered } \\
\text { forklifts were deployed at a } \\
\text { North Carolina production } \\
\text { center. Both sites use Plug } \\
\text { Power fuel cells. }\end{array}$ & \\
\hline $\begin{array}{l}\text { FreezPak } \\
\text { Logistics }\end{array}$ & $\begin{array}{l}\text { FreezPak Logistics operates } \\
40 \text { Plug Power fuel cell forklifts } \\
\text { at its "around-the-clock" cold } \\
\text { storage distribution freezer } \\
\text { warehouse in New Jersey. }\end{array}$ & $\begin{array}{l}\text { In August 2016, FreezePak was } \\
\text { named one of Food Logistics' } \\
2006 \text { Top 3PL \& Cold Storage } \\
\text { Providers. }{ }^{40}\end{array}$ \\
\hline Kellogg Company & $\begin{array}{l}\text { The 1-MW Bloom Energy } \\
\text { Server generates } \\
\text { approximately half of the } \\
\text { annual electrical consumption } \\
\text { at Kellogg's San Jose, } \\
\text { California, Eggo bakery and } \\
\text { uses less water to generate } \\
\text { this power than if it had been } \\
\text { supplied by the utility grid. }\end{array}$ & $\begin{array}{l}\text { Kellogg says of their fuel cell } \\
\text { experience: "This is the first time } \\
\text { Kellogg has explored this sort of } \\
\text { thing and it was motivated } \\
\text { directly by the emissions } \\
\text { reduction target. ... we are } \\
\text { looking to replicate it at another } \\
\text { facility." }{ }^{41} \\
\text { The project has led to an } \\
\text { estimated } 2,700,000 \text { lbs. of } \mathrm{CO}_{2} \\
\text { reductions a year. }{ }^{42}\end{array}$ \\
\hline
\end{tabular}




\begin{tabular}{|c|c|c|}
\hline \multicolumn{3}{|c|}{$\begin{array}{c}\text { Examples of Companies that Rely on Fuel Cells: } \\
\text { Grocers, Food \& Logistics }\end{array}$} \\
\hline COMPANY & BACKGROUND & UPDATE \\
\hline $\begin{array}{c}\text { Newark Farmer's } \\
\text { Market }\end{array}$ & $\begin{array}{l}\text { In 2011, Newark Farmer's } \\
\text { Market deployed more than } \\
100 \text { Plug Power GenDrive fuel } \\
\text { cell-powered forklifts at its } \\
\text { refrigerated warehouse and } \\
\text { distribution center in Newark, } \\
\text { New Jersey. In 2014, } 110 \text { new } \\
\text { GenDrive fuel cells and a } \\
\text { GenFuel hydrogen fueling } \\
\text { system were added at its new } \\
\text { state-of-the-art food } \\
\text { distribution center, bringing its } \\
\text { fuel cell MHE fleet to more } \\
\text { than } 240 .\end{array}$ & $\begin{array}{l}\text { Newark Farmer's Market } \\
\text { ordered } 96 \text { next generation Plug } \\
\text { Power GenDrive units to replace } \\
\text { its original fuel cell material } \\
\text { handling fleet in July } 2016 .^{43}\end{array}$ \\
\hline Pacific Cheese & $\begin{array}{l}\text { Pacific Cheese uses a } 300-\mathrm{kW} \\
\text { Bloom Energy fuel cell system } \\
\text { to produce power at its } \\
\text { Hayward, California, site. }\end{array}$ & $\begin{array}{l}\text { The use of Bloom Energy fuel } \\
\text { cells has resulted in an } \\
\text { estimated } 820,000 \text { lbs. of } \mathrm{CO}_{2} \\
\text { reductions per year at Pacific } \\
\text { Cheese. }{ }^{44}\end{array}$ \\
\hline
\end{tabular}




\section{Examples of Companies that Rely on Fuel Cells: \\ Grocers, Food \& Logistics}

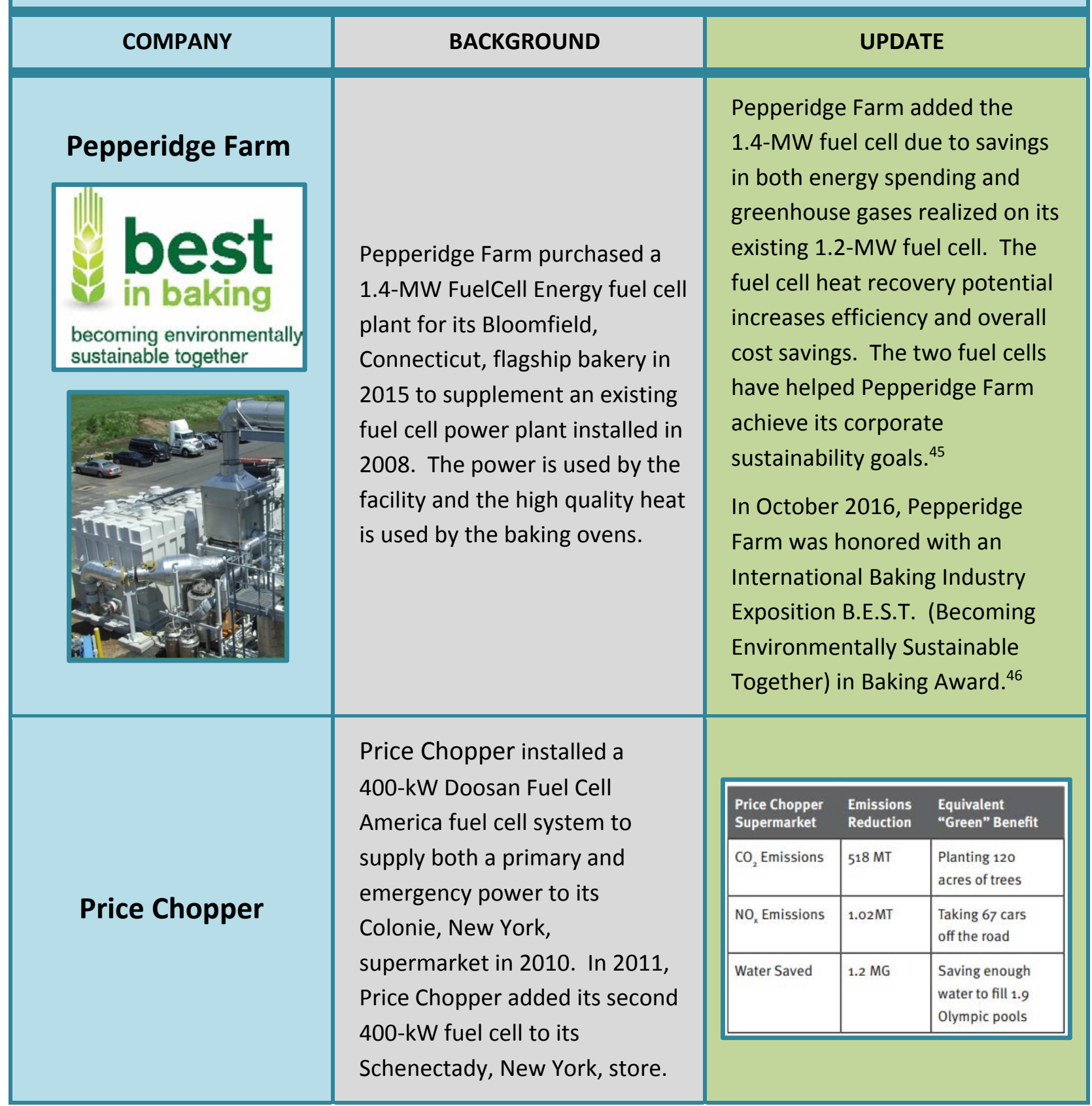




\begin{tabular}{|c|c|c|}
\hline \multicolumn{3}{|c|}{$\begin{array}{l}\text { Examples of Companies that Rely on Fuel Cells: } \\
\text { Grocers, Food \& Logistics }\end{array}$} \\
\hline COMPANY & BACKGROUND & UPDATE \\
\hline Ramar Foods & $\begin{array}{l}\text { Ramar installed a } 200-\mathrm{kW} \\
\text { Bloom Energy Server at its } \\
\text { Pittsburg, California, } \\
\text { manufacturing and packaging } \\
\text { facility in } 2013 \text {. The system } \\
\text { provides } 65 \% \text { of the electricity } \\
\text { needs for the facility, which } \\
\text { manufactures the company's } \\
\text { brands of Filipino and Asian } \\
\text { frozen foods. }\end{array}$ & $\begin{array}{l}\text { The use of the Bloom Energy } \\
\text { fuel cell has resulted in an } \\
\text { estimated } 540,000 \text { lbs. of } \mathrm{CO}_{2} \\
\text { reductions at Ramar Foods } \\
\text { annually. }{ }^{47}\end{array}$ \\
\hline Safeway & $\begin{array}{l}\text { In 2010, a new Safeway Santa } \\
\text { was opened in Santa Cruz, } \\
\text { California, featuring two } \\
\text { 100-KW Bloom Energy Server } \\
\text { fuel cells and a solar array on } \\
\text { its roof. }\end{array}$ & $\begin{array}{l}\text { This project has resulted in an } \\
\text { estimated } 540,000 \mathrm{lbs} \text {. of } \mathrm{CO}_{2} \\
\text { reductions per year for } \\
\text { Safeway. }{ }^{48}\end{array}$ \\
\hline $\begin{array}{l}\text { Sierra Nevada } \\
\text { Brewery }\end{array}$ & $\begin{array}{l}\text { Sierra Nevada utilized } 1 \mathrm{MW} \text { of } \\
\text { fuel cells to provide power at } \\
\text { Chico, California, brewery from } \\
2005 \text { until } 2015 \text {. }\end{array}$ & $\begin{array}{l}\text { Sierra Nevada Brewery now uses } \\
\text { Altergy fuel cells to provide } \\
\text { backup power for refrigeration } \\
\text { systems in beer trailers. The } \\
\text { fuel cells help eliminate noise } \\
\text { and pollution for guests at their } \\
\text { events. }{ }^{49} 50\end{array}$ \\
\hline
\end{tabular}




\begin{tabular}{|c|c|c|}
\hline \multicolumn{3}{|c|}{$\begin{array}{l}\text { Examples of Companies that Rely on Fuel Cells: } \\
\text { Grocers, Food \& Logistics }\end{array}$} \\
\hline COMPANY & BACKGROUND & UPDATE \\
\hline Benestion & $\begin{array}{l}\text { In 2011, Stone Edge Farm, an } \\
\text { organic farm and winery } \\
\text { located in Sonoma Valley, } \\
\text { California, installed its first } \\
5-\mathrm{kW} \text { fuel cell system to } \\
\text { provide CHP to the winery's } \\
\text { estate and vineyard, helping } \\
\text { reduce the energy required to } \\
\text { run the irrigation system and } \\
\text { lights and warm the } \\
11,000 \text {-gallon lap pool. }\end{array}$ & $\begin{array}{l}\text { Stone Edge now operates its } \\
\text { own state-of-the-art micro-grid } \\
\text { to provide sustainable energy for } \\
\text { facility operations. The micro- } \\
\text { grid includes } 26 \text { kW of Plug } \\
\text { Power GenSure fuel cells to help } \\
\text { power servers, fiber, Ethernet, } \\
\text { gates, alarms and security } \\
\text { lighting. The hydrogen is } \\
\text { generated renewably from a } \\
\text { Millennium Reign Energy system } \\
\text { via solar-power electrolysis and } \\
\text { also provides fuel for the } \\
\text { winery's multiple fuel cell } \\
\text { vehicles. } \\
\text { To help promote its zero } \\
\text { emission micro-grid solution to } \\
\text { other regional wineries, Stone } \\
\text { Edge Farm hosted an open } \\
\text { house, featuring a Luxfer-GTM } \\
\text { fuel cell mobile lighting system. }\end{array}$ \\
\hline $\ln _{1}||_{1} \mid$ & $\begin{array}{l}\text { Grocer Stop \& Shop installed a } \\
\text { Doosan Fuel Cell America 400- } \\
\text { kW fuel cell system at its } \\
\text { Torrington, Connecticut, store } \\
\text { to generate more than } 90 \% \text { of } \\
\text { the store's electrical power. } \\
\text { In 2014, Stop \& Shop added its } \\
\text { second fuel cell system, a } \\
250-k W \text { Bloom Energy Server, } \\
\text { at its Mt. Vernon, New York, } \\
\text { grocery store. }\end{array}$ & $\begin{array}{l}\text { The Mt. Vernon project has led } \\
\text { to an estimated } 1,300,000 \text { lbs. of } \\
\mathrm{CO}_{2} \text { reductions annually. } .^{52}\end{array}$ \\
\hline
\end{tabular}




\begin{tabular}{|c|c|c|}
\hline \multicolumn{3}{|c|}{$\begin{array}{l}\text { Examples of Companies that Rely on Fuel Cells: } \\
\text { Grocers, Food \& Logistics }\end{array}$} \\
\hline COMPANY & BACKGROUND & UPDATE \\
\hline $\begin{array}{c}\text { Sutter Home } \\
\text { Winery }\end{array}$ & $\begin{array}{l}\text { Sutter Home Winery, the fifth } \\
\text { largest winery in U.S., installed } \\
\text { two 200-kW Bloom Energy fuel } \\
\text { cells in } 2011 \text { at its St. Helena, } \\
\text { California, winery to offset the } \\
\text { baseload electricity usage on } \\
\text { two utility meters. }\end{array}$ & $\begin{array}{l}\text { The fuel cell helped Sutter Home } \\
\text { save } \$ 192,437 \text { in energy costs } \\
\text { during its first year of } \\
\text { operation. }{ }^{53} \\
\text { The winery also reduces its } \mathrm{CO}_{2} \\
\text { emissions by an estimated } \\
1,000,000 \text { lbs. per year. }{ }^{54}\end{array}$ \\
\hline $\begin{array}{l}\text { The Wonderful } \\
\text { Company }\end{array}$ & $\begin{array}{l}\text { The Wonderful Company has } \\
\text { installed Bloom Energy fuel } \\
\text { cells at its six primary locations } \\
\text { in California, including a } \\
250-\mathrm{kW} \text { fuel cell its } \\
\text { headquarters in Los Angeles; } \\
2 \mathrm{MW} \text { at two facilities in } \\
\text { Delano, including a Paramount } \\
\text { Citrus Wonderful Company } \\
\text { Halos packinghouse facility; } \\
400 \mathrm{~kW} \text { at Paramount Farms in } \\
\text { Lost Hills; and } 400 \text { kW at its } \\
\text { POM Wonderful facility in Del } \\
\text { Rey. }\end{array}$ & $\begin{array}{l}\text { Annually, The Wonderful } \\
\text { Company is reducing its } \mathrm{CO}_{2} \\
\text { emissions by an estimated } \\
8,000,000 \text { lbs. }^{55}\end{array}$ \\
\hline
\end{tabular}




\section{Examples of Companies that Rely on Fuel Cells: \\ Grocers, Food \& Logistics}

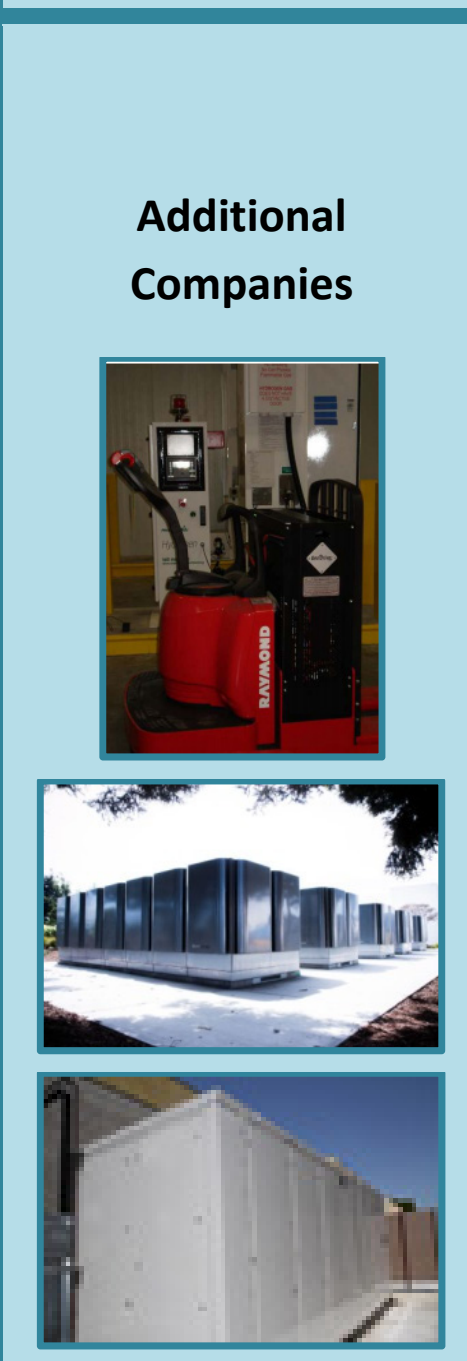

Top to bottom: Fuel cellpowered forklift and hydrogen fueling at a Sysco site; Bloom Energy fuel cell system at Taylor Farms, Doosan fuel cell system at a Whole Foods store

\section{BACKGROUND}

Kroger trialed Plug Power's fuel cell systems on forklifts at an Ohio facility in 2010, then ordered 182 fuel cells to replace batteries in forklifts at a California distribution center. In 2014, Kroger ordered more fuel cells for distribution centers Colorado and Kentucky.

Sysco, a marketer and distributor of foodservice products, operates more than 800 fuel cell-powered forklifts at seven distribution facilities in the U.S. In a DOE-sponsored project, Sysco, with Plug Power, Carrier Transicold and Air Products, performed four 400 hour demonstrations of a fuel cell-powered auxiliary power unit on a multi-temperature trailer, replacing diesel engines.

Taylor Farms, a producer of fresh-cut fruits and vegetables, generates power using a 1-MW Bloom Energy fuel cell system that reduces the facility's carbon footprint by up to $30 \%$ and water used by $99.99 \%$.

UNFI operates 83 Plug Power fuel cell forklifts at a Florida distribution center.

Wegmans retail service center in Pennsylvania operates 315 forklifts powered by Plug Power fuel cell systems.

WinCo Foods' distribution center in Modesto, California, operates 161 forklifts powered by Plug Power GenDrive fuel cells. The site uses Air Products' hydrogen fueling technology and infrastructure.

Whole Foods operates a 400-kW Doosan system, installed in 2011, at its Fairfield, Connecticut, retail site to generate $90 \%$ of the store's electricity needs, with byproduct thermal energy used for store heating, cooling and refrigeration. Whole Foods also uses a 400-kW Doosan system to provide power at its San Jose, California, store. In addition, Whole Foods operates more than 50 fuel cell-powered forklifts supplied by Plug Power, in its Landover, Maryland, distribution center. 


\section{Spotlight on Super Bowl 50}

As featured in the State of the States: Fuel Cells in America 2016 report, Super Bowl 50, held in Santa Clara, California, showcased sustainability by having fuel cells play a big role in lighting the streets and stages of Super Bowl City.

Fuel cells also helped the Sonoma Wine Lounge and Market Street Bistro in Super Bowl City keep fans fed and happy for nine days leading up to the main event. Luxfer-GTM provided its Zero-Set mobile fuel cell generators, using renewably-generated hydrogen sourced from the Stone Edge Farm winery's micro-grid.
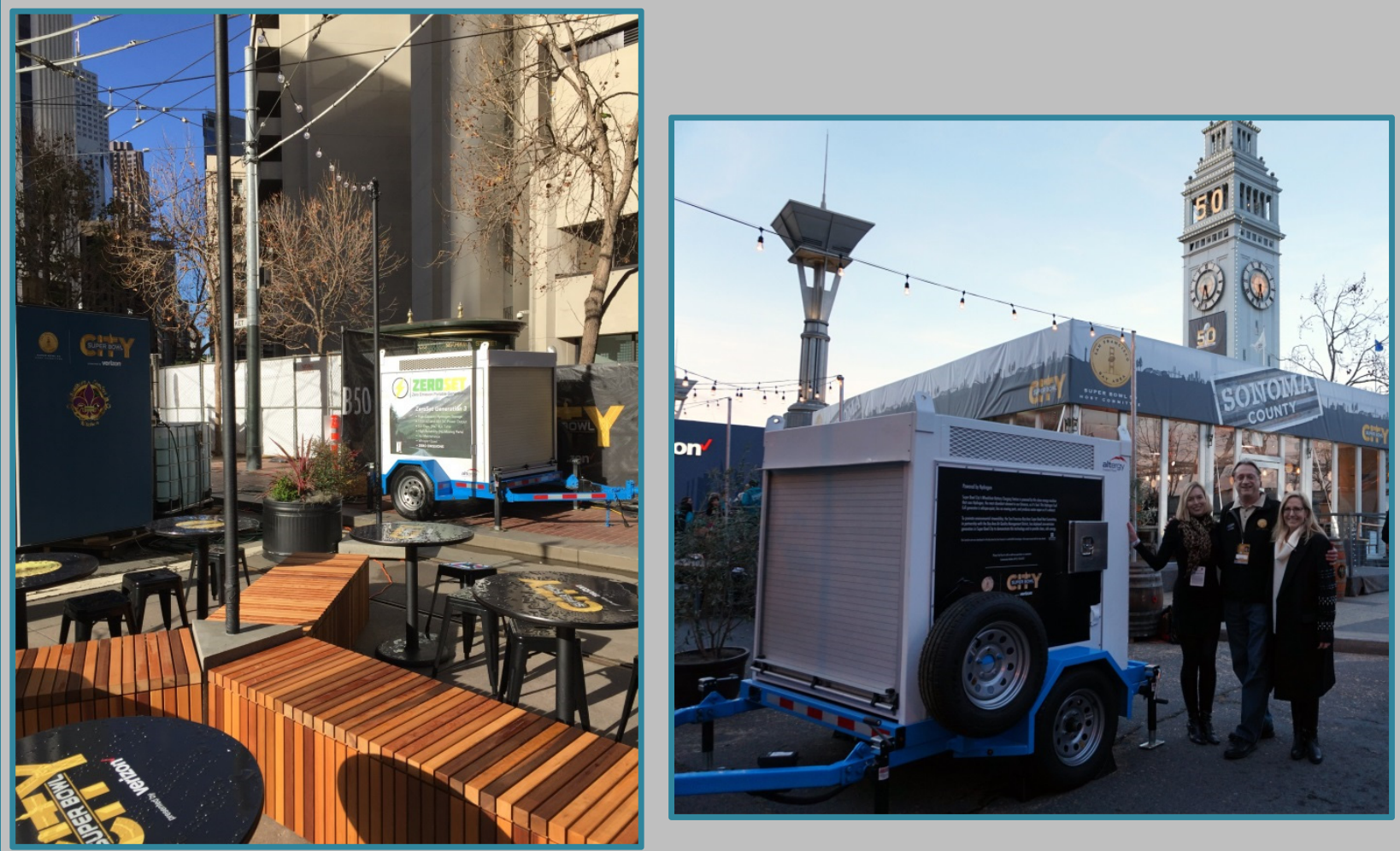

"It was quite exciting to be able to build our clean energy initiatives around Super Bowl City with the help of Luxfer-GTM and the Zero Emission Generators. With the addition of this technology, we were able to power SBC $100 \%$ away from dirty diesel. We had over a million guests in the 9-day course of our event, and many of them were pleased to learn about hydrogen fuel cell generators and see them in action on a large scale event. It was exciting for us and for the community who came to enjoy Super Bowl City."

\section{John Mitchell}

Director of Event Production

San Francisco Bay Area Super Bowl 50 Host Committee 


\section{Industrial \& Consumer Products}

Fuel cells are helping support the industry that supports industry. Companies that manufacture machinery, materials, and components for use in further processing by other industries are installing fuel cells to help reduce emissions and provide reliable power.

Similarly, companies making products for distribution to retail stores across the country are using fuel cells for onsite power generation, as well as power for material handling vehicles used to move goods in manufacturing facilities.

\begin{tabular}{|c|c|c|}
\hline \multicolumn{3}{|c|}{$\begin{array}{l}\text { Examples of Companies that Rely on Fuel Cells: } \\
\text { Industrial \& Consumer Products }\end{array}$} \\
\hline COMPANY & BACKGROUND & UPDATE \\
\hline Baker Hughes & $\begin{array}{l}\text { In 2012, Baker Hughes, an } \\
\text { oilfield services company, } \\
\text { installed a 300-kW Bloom Energy } \\
\text { fuel cell system to supply } \\
60 \text { percent of the power to the } \\
\text { main office, laboratories, and } \\
\text { vehicle maintenance workshop } \\
\text { at its new } 70 \text {-acre integrated } \\
\text { campus in Shafter, California. }\end{array}$ & $\begin{array}{l}\text { Baker Hughes was the first } \\
\text { company to install a fuel cell at } \\
\text { an industrial site. The company } \\
\text { reported that it invested } \\
\$ 2.7 \text { million with a payback } \\
\text { period of } ~ 3 \text { years based on } \\
\text { incentives and reduced } \\
\text { electricity costs. Baker } \\
\text { expected "to realize electricity } \\
\text { cost savings of approximately a } \\
\text { half million dollars per year, or } \\
45 \% \text { over a standard facility of } \\
\text { this size." }{ }^{\prime \prime 5}\end{array}$ \\
\hline $\begin{array}{l}\text { Bridgestone- } \\
\text { Firestone }\end{array}$ & $\begin{array}{l}\text { Since } 2008 \text {, the Graniteville, } \\
\text { South Carolina, and Morrison, } \\
\text { Tennessee, tire manufacturing } \\
\text { plants have utilized Plug Power } \\
\text { GenDrive fuel cells to power } \\
\text { material handling equipment. } \\
\text { The facilities operate } 25 \text { and } \\
48 \text { units respectively. }\end{array}$ & $\begin{array}{l}\text { In addition to being a fuel cell } \\
\text { customer, Bridgestone } \\
\text { announced in March } 2016 \text { that } \\
\text { its ECOPIA brand of tires are } \\
\text { featured as standard equipment } \\
\text { on the Honda Clarity fuel cell } \\
\text { vehicle. }{ }^{57}\end{array}$ \\
\hline
\end{tabular}




\begin{tabular}{|c|c|c|}
\hline \multicolumn{3}{|c|}{$\begin{array}{l}\text { Examples of Companies that Rely on Fuel Cells: } \\
\text { Industrial \& Consumer Products }\end{array}$} \\
\hline COMPANY & BACKGROUND & UPDATE \\
\hline Maxim Integrated & $\begin{array}{l}\text { Maxim Integrated, a } \\
\text { manufacturer of analog and } \\
\text { mixed-signal integrated circuits, } \\
\text { installed a 1-MW Bloom Energy } \\
\text { fuel cell system at its San Jose, } \\
\text { California, headquarters in } 2014 .\end{array}$ & $\begin{array}{l}\text { Maxim reports that the fuel cell } \\
\text { reduces the site's carbon } \\
\text { footprint by } \sim 20 \% . .^{58}\end{array}$ \\
\hline $\begin{array}{l}\text { Owens Corning } \\
\text { find }\end{array}$ & $\begin{array}{l}\text { In 2011, Owens Corning installed } \\
\text { two } 200-k W \text { Bloom Energy } \\
\text { Servers that provide 65\% of the } \\
\text { Compton, California, plant's } \\
\text { power annually. In } 2012 \text {, Owens } \\
\text { Corning received } \$ 1.2 \text { million in } \\
\text { funding through the New Jersey } \\
\text { CHP-Fuel Cell Program for its } \\
\text { Kearny, New Jersey, } 525-k W \text { fuel } \\
\text { cell installation. }\end{array}$ & $\begin{array}{l}\text { The fuel cell in Compton, } \\
\text { California, has resulted in more } \\
\text { than } 1,000,000 \mathrm{lbs} \text {. of } \mathrm{CO}_{2} \\
\text { reductions per year } \\
\text { (estimated). }{ }^{59}\end{array}$ \\
\hline $\begin{array}{l}\text { TaylorMade-Adidas } \\
\text { Golf Company }\end{array}$ & $\begin{array}{l}\text { TaylorMade-Adidas added a } \\
300-k W \text { Bloom Energy Server to } \\
\text { generate power at its } \\
\text { manufacturing facility in } \\
\text { Carlsbad, California. }\end{array}$ & $\begin{array}{l}\text { The Adidas Group's "Green } \\
\text { Company Performance Analysis } \\
2014 \text { " report notes: "The fuel } \\
\text { cell in Carlsbad reforms natural } \\
\text { gas into electricity at an } \\
\text { efficiency rate of } 52-60 \% \text {, which } \\
\text { is considerably more efficient } \\
\text { than the traditional electricity } \\
\text { grid ( } \sim 30 \% \text { ), and reduces carbon } \\
\text { emissions from electricity at the } \\
\text { site." } 60 \\
\text { The Bloom Energy fuel cell } \\
\text { system has led to an estimated } \\
820,000 \mathrm{lbs} \text {. of } \mathrm{CO}_{2} \text { reductions } \\
\text { per year. }\end{array}$ \\
\hline
\end{tabular}




\section{Examples of Companies that Rely on Fuel Cells: Industrial \& Consumer Products}

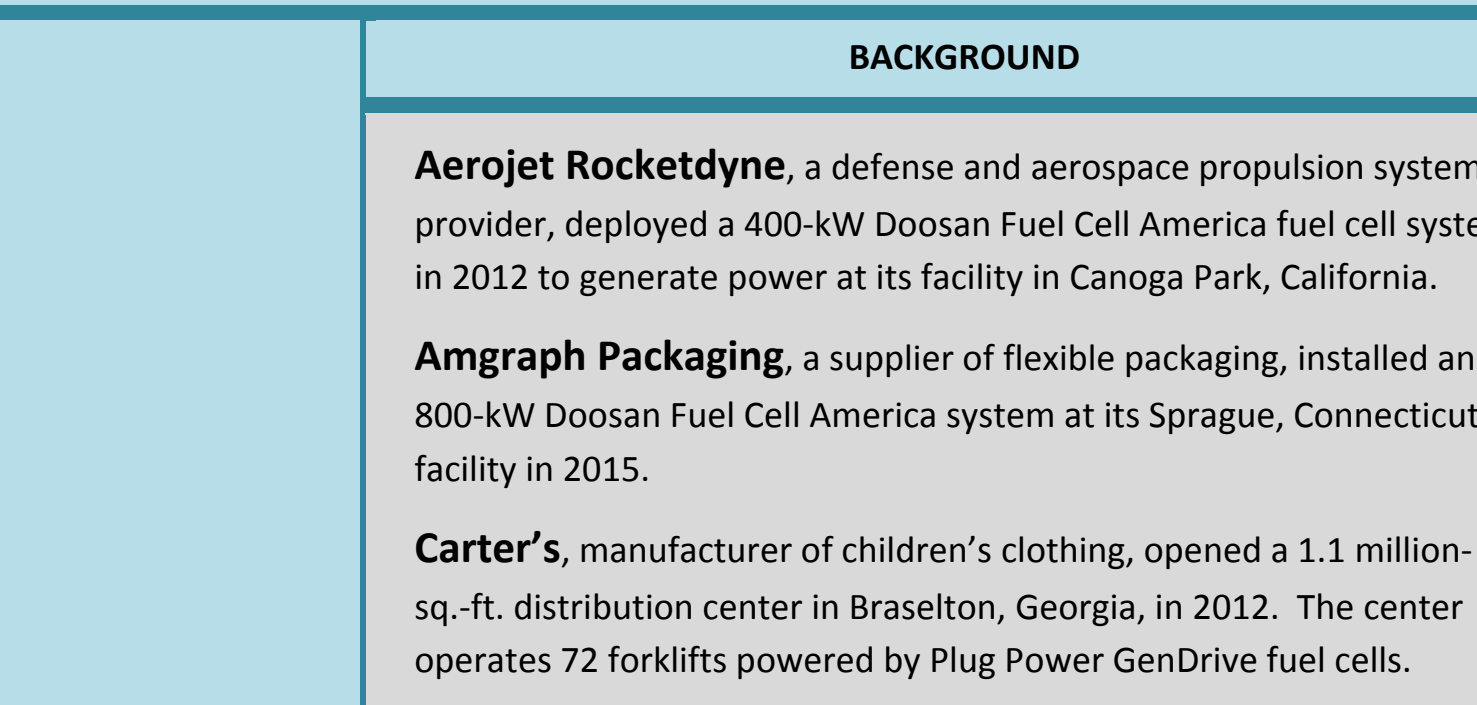

Kimberly-Clark, a supplier of personal and healthcare products, has 28 fuel cell forklifts in operation at its Graniteville, South Carolina, manufacturing facility. The fuel cells were provided by Plug Power.

Additional Companies
LeGrand North America, a global specialist in electrical and digital building infrastructures, installed a 500-kW Bloom Energy fuel cell in April 2016 to supply up to $88 \%$ of the power used at the West Hartford, Connecticut, headquarters and manufacturing campus. The company anticipates that carbon emissions could be lowered by half and the fuel cell will save Legrand up to $\$ 2.4$ million over the next decade.

Pratt \& Whitney, an aerospace manufacturer, installed two Doosan Fuel Cell America fuel cells to generate power at its Middletown, Connecticut, facility in 2011.

Procter \& Gamble, manufacturer of family, personal and household care products, operates more than 400 fuel cell-powered forklifts at 4 different manufacturing facilities: Oxnard, California; Pineville, Louisiana; Greensboro, North Carolina; and Mehoopany, Pennsylvania. Plug Power supplied the fuel cells.

SC Johnson, manufacturer of household cleaning supplies and other consumer chemicals, will use a 400-kW Doosan Fuel Cell America system to supply power at its Sturtevant, Wisconsin, facility. 


\section{Examples of Companies that Rely on Fuel Cells: Consumer \& Industrial Products}

\begin{tabular}{|l|l}
\hline \multirow{2}{*}{ Additional } & \multicolumn{1}{c}{ BACKGROUND } \\
\cline { 2 - 3 } Companies & $\begin{array}{l}\text { Stihl, a power equipment manufacturer, deployed } 33 \text { Plug Power fuel } \\
\text { cells to power forklifts at its Norfolk, Virginia, site in } 2012 .\end{array}$ \\
& $\begin{array}{l}\text { Uline, a family-owned distributor of shipping, industrial and packaging } \\
\text { materials, deployed more than } 130 \text { Plug Power GenDrive-powered lift } \\
\text { trucks at two Pleasant Prairie, Wisconsin, facilities in 2014, along with a } \\
\text { Plug Power GenFuel hydrogen system with eight dispensers. }\end{array}$ \\
\hline
\end{tabular}




\section{Technology \& Telecommunications}

The technology companies customers rely on daily are, in turn, relying on fuel cells to provide uninterrupted power to the data and call centers that protect private information and process countless global transactions. They are also installing fuel cells at headquarters to keep daily operations running smoothly while reducing emissions.

Telecommunications companies have deployed fuel cells all at sites across the world to ensure consitent primary or backup power for a range ofsystems that require reliable, on-site, direct DC power supply. The reasons are many - for backup power, fuel cells provide a better total cost of ownership, are clean and quiet, fuel flexible, and boast longer runtimes than batteries. They also use less space and are lighter than batteries or generators, so are able to be sited on rooftops, and are rugged and durable, allowing for siting off the beaten path in rural and remote areas.

\begin{tabular}{|c|c|c|}
\hline \multicolumn{3}{|c|}{$\begin{array}{c}\text { Examples of Companies that Rely on Fuel Cells: } \\
\text { Technology \& Telecommunications }\end{array}$} \\
\hline COMPANY & BACKGROUND & UPDATE \\
\hline Adobe & $\begin{array}{l}\text { In 2010, Adobe installed 1.2-MW } \\
\text { of Bloom Energy Servers at its San } \\
\text { Jose, California, headquarters. In } \\
2011 \text {, Adobe added a second } \\
\text { Bloom Energy site with a 400-kW } \\
\text { fuel cell installation at its } \\
\text { downtown San Francisco, } \\
\text { California, offices. }\end{array}$ & $\begin{array}{l}\text { Adobe reports the amount of } \\
\text { fuel cell electricity produced } \\
\text { during the fiscal year (Nov. } 29 \text {, } \\
2014-N o v .27,2015 \text { ) was } \\
9,780 \mathrm{MWh} \text {, with fuel cell- } \\
\text { generated power comprising } \\
12.1 \% \text { of the company's energy } \\
\text { use. }{ }^{62} \\
\text { The San Jose fuel cell system is } \\
\text { reducing } \mathrm{CO}_{2} \text { emissions by an } \\
\text { estimated 3,200,000 Ibs. } \\
\text { annually, while the San Francisco } \\
\text { project achieving } 1,000,000 \text { Ibs. } \\
\text { of } \mathrm{CO}_{2} \text { reductions per year. }{ }^{63}\end{array}$ \\
\hline
\end{tabular}




\begin{tabular}{|c|c|c|}
\hline \multicolumn{3}{|c|}{$\begin{array}{c}\text { Examples of Companies that Rely on Fuel Cells: } \\
\text { Technology \& Telecommunications }\end{array}$} \\
\hline COMPANY & BACKGROUND & UPDATE \\
\hline Apple & $\begin{array}{l}\text { Apple's Maiden, North Carolina, } \\
\text { iCloud data center has gone } \\
\text { completely off the grid by } \\
\text { combining a 10-MW Bloom } \\
\text { Energy fuel cell system with solar } \\
\text { generation. }\end{array}$ & $\begin{array}{l}\text { Apple announced it will also be } \\
\text { powering part of its new } \\
\text { Cupertino, California, campus } \\
\text { with Bloom Energy fuel cells. } \\
\text { The building will be powered by } \\
100 \% \text { renewable energy, } \\
\text { generated by } 4 \mathrm{MW} \text { of fuel cells } \\
\text { and } 16 \mathrm{MW} \text { of rooftop solar. }\end{array}$ \\
\hline 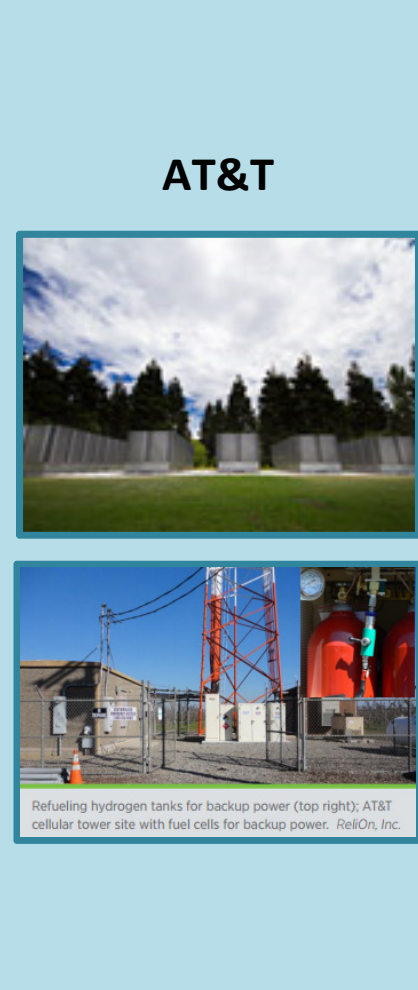 & $\begin{array}{l}\text { At the end of 2015, AT\&T's } \\
\text { alternative energy portfolio } \\
\text { included } 20.9 \mathrm{MW} \text { of onsite fuel } \\
\text { cell power from Bloom Energy } \\
\text { fuel cell servers across four } \\
\text { states (California, Connecticut, } \\
\text { New Jersey, New York). } \\
\text { AT\&T also uses Plug Power } \\
\text { (formerly ReliOn) fuel cells at cell } \\
\text { towers to provide backup power, } \\
\text { ensuring that they will function } \\
\text { when grid power goes down. The } \\
\text { company has } 180 \text { fuel cell } \\
\text { systems deployed at towers } \\
\text { across } 10 \text { states: Arizona, } \\
\text { California, Colorado, Florida, } \\
\text { Illinois, Indiana, Kentucky, } \\
\text { Michigan, New Mexico, and Utah. }\end{array}$ & $\begin{array}{l}\text { During } 2015, \text { AT\&T added Bloom } \\
\text { Energy servers at three } \\
\text { additional sites in California and } \\
\text { two in New Jersey, totaling } \\
4.35 \mathrm{MW} \text { of onsite fuel cell } \\
\text { power generation. }{ }^{65} \\
\text { As of September } 2016 \text {, all of } \\
\text { AT\&T's fuel cell projects have } \\
\text { resulted in a total of } \\
76,624,904 \text { lbs. of } \mathrm{CO}_{2} \\
\text { reductions. }{ }^{66}\end{array}$ \\
\hline
\end{tabular}




\begin{tabular}{|c|c|c|}
\hline \multicolumn{3}{|c|}{$\begin{array}{c}\text { Examples of Companies that Rely on Fuel Cells: } \\
\text { Technology \& Telecommunications }\end{array}$} \\
\hline COMPANY & BACKGROUND & UPDATE \\
\hline CenturyLink & $\begin{array}{l}\text { In 2014, communications and } \\
\text { data company CenturyLink } \\
\text { installed a 500-kW Bloom Energy } \\
\text { fuel cell. The system produces } \\
\text { nearly } 4.4 \text { million kWh of annual } \\
\text { electricity and helps to power } \\
\text { cloud, and managed hosting and } \\
\text { colocation services housed within } \\
\text { the Irvine, California, data center. }\end{array}$ & $\begin{array}{l}\text { The project has resulted in an } \\
\text { estimated } 1,300,000 \mathrm{lbs} \text {. of } \mathrm{CO}_{2} \\
\text { reductions annually. }{ }^{67}\end{array}$ \\
\hline Comcast & $\begin{array}{l}\text { A 400-kW Bloom Energy fuel cell } \\
\text { system was installed in } 2015 \text { to } \\
\text { power Comcast's Western New } \\
\text { England Regional Headquarters in } \\
\text { Berlin, Connecticut. }\end{array}$ & $\begin{array}{l}\text { Comcast's Connecticut fuel cell } \\
\text { has reduced } \mathrm{CO}_{2} \text { each year by an } \\
\text { estimated } 1,400,000 \text { lbs. }^{68}\end{array}$ \\
\hline $\begin{array}{c}\text { Cox } \\
\text { Communications }\end{array}$ & $\begin{array}{l}\text { Cox uses fuel cells to provide } \\
\text { power at California sites. These } \\
\text { include: } \\
\text { Bloom Energy installations in } \\
\text { Oakland ( } 400 \mathrm{~kW}) \text { and El Cajon } \\
(600 \mathrm{~kW}) . \\
\text { Doosan Fuel Cell America } \\
\text { installations in San Diego } \\
(800 \mathrm{~kW}) \text { and Santa Margarita } \\
(800 \mathrm{~kW}) .\end{array}$ & $\begin{array}{l}\text { The Bloom Energy fuel cell fleet } \\
\text { is reducing Cox's } \mathrm{CO}_{2} \text { emissions } \\
\text { by an estimated 2,700,000 lbs. } \\
\text { per year. }{ }^{69}\end{array}$ \\
\hline
\end{tabular}




\begin{tabular}{|c|c|c|}
\hline \multicolumn{3}{|c|}{$\begin{array}{c}\text { Examples of Companies that Rely on Fuel Cells: } \\
\text { Technology \& Telecommunications }\end{array}$} \\
\hline COMPANY & BACKGROUND & UPDATE \\
\hline eBay & $\begin{array}{l}\text { eBay generates power at its LEED } \\
\text { Gold-certified headquarters } \\
\text { building in San Jose, California, } \\
\text { using a 500-kW Bloom Energy } \\
\text { Server, installed in } 2009 . \\
\text { In 2013, eBay opened its data } \\
\text { center in South Jordan, Utah, } \\
\text { which included } 6 \mathrm{MW} \text { of Bloom } \\
\text { Energy Servers and uses the } \\
\text { electric utility grid as backup. }\end{array}$ & $\begin{array}{l}\text { In } 2015 \text {, eBay added } 3.75 \mathrm{MW} \text { to } \\
\text { its Utah data center, bringing its } \\
\text { fuel cell installation to } \\
9.75 \mathrm{MW}^{70} \\
\text { The San Jose, California, } \\
\text { installation lowers } \mathrm{CO}_{2} \text { emissions } \\
\text { each year by an estimated } \\
1,300,000 \text { lbs. The Utah project } \\
\text { now achieves an estimated } \\
79,700,000 \text { lbs. of } \mathrm{CO}_{2} \\
\text { reductions annually. }\end{array}$ \\
\hline Equinix & $\begin{array}{l}\text { Equinix, a global interconnection } \\
\text { and data center company, } \\
\text { generates power using } 1 \mathrm{MW} \\
\text { Bloom Energy fuel cells at its SV5 } \\
\text { International Business Exchange } \\
\text { (IBX } \\
\text { (IM) data center, located in } \\
\text { Silicon Valley, California. }\end{array}$ & $\begin{array}{l}\text { Bloom Energy features an } \\
\text { Equinix customer profile video } \\
\text { on their website. }{ }^{72}\end{array}$ \\
\hline
\end{tabular}




\begin{tabular}{|c|c|c|}
\hline \multicolumn{3}{|c|}{$\begin{array}{c}\text { Examples of Companies that Rely on Fuel Cells: } \\
\text { Technology \& Telecommunications }\end{array}$} \\
\hline COMPANY & BACKGROUND & UPDATE \\
\hline Google & $\begin{array}{l}\text { Google was one of Bloom } \\
\text { Energy's pilot customers, } \\
\text { installing } 400-k W \text { of Bloom } \\
\text { Energy Servers in } 2007 \text { at } \\
\text { Google's main campus in } \\
\text { Mountain View, California. } \\
\text { In 2015, Google installed a } \\
400-k W \text { Bloom Energy fuel cell } \\
\text { system at the same location. }\end{array}$ & $\begin{array}{l}\text { Google's website states: "We } \\
\text { believe that by putting our } \\
\text { dollars and resources behind a } \\
\text { promising new technology-or } \\
\text { allowing companies to use our } \\
\text { campus as a testing ground-the } \\
\text { technology will have a better } \\
\text { chance of making it to market } \\
\text { and scaling. For example, in } \\
\text { 2007, we hosted the first } \\
\text { installation of a promising new } \\
\text { fuel cell technology that has the } \\
\text { potential to use biogas. The } \\
\text { company, also based in the Bay } \\
\text { Area, was able to more quickly } \\
\text { evolve the technology by having } \\
\text { a working real-world pilot } \\
\text { nearby."73 } \\
\text { The } 400-k W \text { fuel cell saves an } \\
\text { estimated } 1,300,000 \text { lbs. of } \mathrm{CO}_{2} \\
\text { emissions per year. }{ }^{74}\end{array}$ \\
\hline
\end{tabular}




\begin{tabular}{|c|c|c|}
\hline \multicolumn{3}{|c|}{$\begin{array}{c}\text { Examples of Companies that Rely on Fuel Cells: } \\
\text { Technology \& Telecommunications }\end{array}$} \\
\hline COMPANY & BACKGROUND & UPDATE \\
\hline Intuit & $\begin{array}{l}\text { Software company Intuit installed } \\
\text { a 500-kW Bloom Energy Server to } \\
\text { generate power at its payment } \\
\text { services facility in Woodland Hills, } \\
\text { California, in } 2012 \text {. }\end{array}$ & $\begin{array}{l}\text { Intuit reports: "in } 2011 \text {, Intuit's } \\
\text { Workplace Services team met to } \\
\text { discuss installing fuel cells at the } \\
\text { Woodland Hills site. After } \\
\text { researching options, the team } \\
\text { discovered that using Bloom } \\
\text { Energy technology would save } \\
\text { Intuit } \$ .04 \text { per kWh. The gas } \\
\text { used to power the fuel cells is } \\
\text { cheaper than electricity from the } \\
\text { Los Angeles Department of } \\
\text { Water and Power, which meant } \\
\text { that after state and federal } \\
\text { incentives for renewable energy, } \\
\text { the Bloom Boxes would be } \\
\text { better for the environment and } \\
\text { cheaper for Intuit."75 } \\
\text { The Woodland Hills project has } \\
\text { resulted in an estimated } \\
1,300,000 \text { Ibs. of } \mathrm{CO}_{2} \text { reductions } \\
\text { per year. }{ }^{76}\end{array}$ \\
\hline Juniper Networks & $\begin{array}{l}\text { Juniper Networks, a network } \\
\text { developer, has } 1 \mathrm{MW} \text { of Bloom } \\
\text { Energy fuel cells operating at its } \\
\text { Sunnyvale, California, corporate } \\
\text { campus. }\end{array}$ & $\begin{array}{l}\text { Juniper Networks' fuel cells, } \\
\text { combined with } 300 \mathrm{~kW} \text { of solar } \\
\text { panels and other energy saving } \\
\text { technologies, are helping } \\
\text { Juniper save more than } \\
\$ 120,000 \text { on the electric bill. }{ }^{77} \\
\text { The project at Juniper Networks } \\
\text { has led to an estimated } \mathrm{CO}_{2} \\
\text { reduction of } 2,700,000 \mathrm{lbs} \\
\text { annually. }\end{array}$ \\
\hline
\end{tabular}




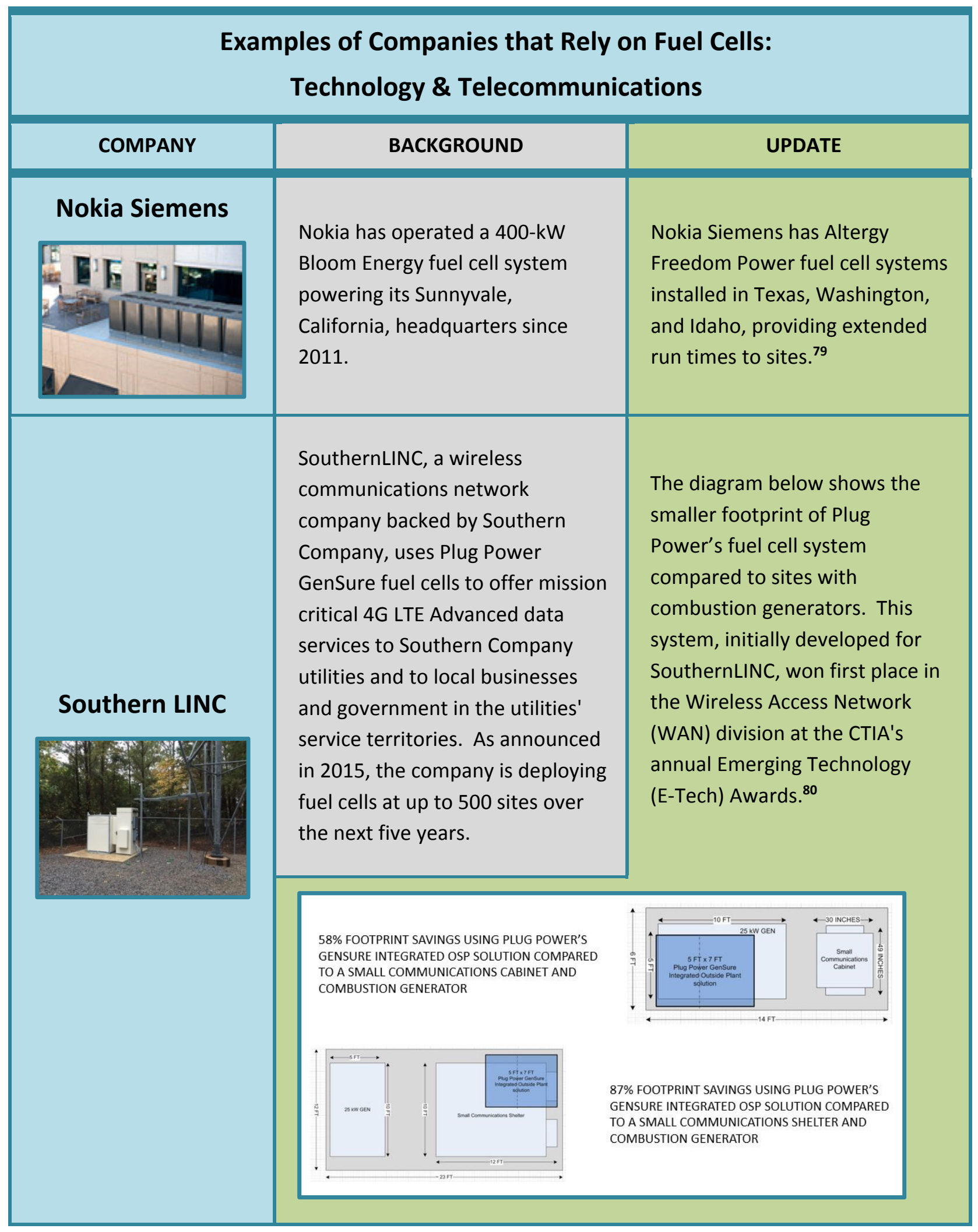




\begin{tabular}{|c|c|c|}
\hline \multicolumn{3}{|c|}{$\begin{array}{c}\text { Examples of Companies that Rely on Fuel Cells: } \\
\text { Technology \& Telecommunications }\end{array}$} \\
\hline COMPANY & BACKGROUND & UPDATE \\
\hline 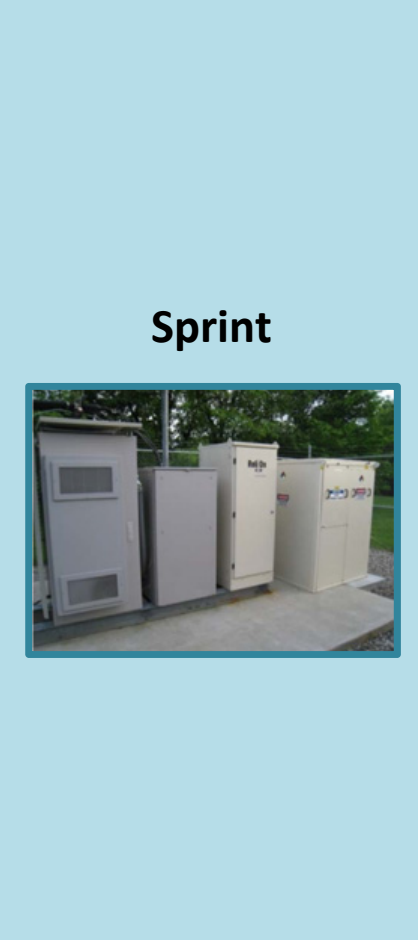 & $\begin{array}{l}\text { Sprint has about } 500 \text { Plug Power } \\
\text { GenSure (formerly ReliOn) and } \\
\text { Altergy fuel cells providing } \\
\text { backup power at telecom towers } \\
\text { and rooftop systems nationwide. } \\
\text { Sprint's } 56 \text { fuel cell backup power } \\
\text { systems in New York, New Jersey } \\
\text { and Connecticut provided more } \\
\text { than } 72 \text { hours of continuous } \\
\text { operation during power outages } \\
\text { caused by Hurricane Irene. }\end{array}$ & $\begin{array}{l}\text { Sprint also has Altergy Freedom } \\
\text { Power fuel cell systems installed } \\
\text { at numerous wireless cell tower } \\
\text { sites in California, Texas, New } \\
\text { York and New Jersey. } \\
\text { Sprint aims to make renewable } \\
\text { sources } 10 \% \text { of the total } \\
\text { electricity used by } 2017 \text { and this } \\
\text { effort includes continuing its } \\
\text { leadership in hydrogen fuel cells. } \\
\text { Headquartered in Kansas, Sprint } \\
\text { reports that, in } 2014 \text {, it provided } \\
\text { testimony to the Kansas House } \\
\text { Subcommittee to help expand } \\
\text { the use of fuel cells as a back-up } \\
\text { power option for Sprint and } \\
\text { other companies. }{ }^{8182}\end{array}$ \\
\hline Time Warner Cable & $\begin{array}{l}\text { In 2010, Time Warner Cable } \\
\text { installed a 30-kW Altergy } \\
\text { Freedom Power fuel cell at its } \\
\text { Palm Springs, California, } \\
\text { distribution hub facility. Time } \\
\text { Warner Cable utilizes a time- } \\
\text { saving, fill-in-place system, which } \\
\text { enables the replacement of } \\
\text { hydrogen in the fuel cells } \\
\text { without switching cylinders. }\end{array}$ & $\begin{array}{l}\text { Time Warner Cable deployed } \\
\text { additional Altergy Freedom } \\
\text { Power fuel cells for backup } \\
\text { power to their cable head end } \\
\text { operations in California and } \\
\text { North Carolina, eliminating } \\
\text { generators and greatly reducing } \\
\text { the use of batteries. }\end{array}$ \\
\hline
\end{tabular}




\begin{tabular}{|c|c|c|}
\hline \multicolumn{3}{|c|}{$\begin{array}{c}\text { Examples of Companies that Rely on Fuel Cells: } \\
\text { Technology \& Telecommunications }\end{array}$} \\
\hline COMPANY & BACKGROUND & UPDATE \\
\hline $\begin{array}{l}\text { Doosan fuel cell system at } \\
\text { Verizon's Basking Ridge, } \mathrm{NJ} \\
\text { location }\end{array}$ & $\begin{array}{l}\text { 8.8-MW of Doosan Fuel Cell } \\
\text { America systems provides grid- } \\
\text { parallel power for Verizon's } \\
\text { central offices, datacenters and } \\
\text { administration. These are } \\
\text { located at } 11 \text { facilities in } \\
\text { California, New Jersey, and New } \\
\text { York. } \\
\text { Bloom Energy fuel cell systems } \\
\text { are located two call-switching } \\
\text { centers in Los Angeles and San } \\
\text { Francisco, California, and at a } \\
\text { data center in San Jose, } \\
\text { California. }\end{array}$ & $\begin{array}{l}\text { Doosan reports that its fuel cells } \\
\text { at Verizon facilities have } \\
\text { reduced greenhouse gas } \\
\text { emissions by about } 6000 \text { metric } \\
\text { tons annually. The overall } \\
\text { efficiency of the fuel cell power } \\
\text { plants is } 42-65 \% .^{84}\end{array}$ \\
\hline actis & $\begin{array}{l}\text { Computing solutions company } \\
\text { Xilinx installed 1-MW of Bloom } \\
\text { Energy fuel cells in } 2012 \text { to } \\
\text { provide power at its San Jose, } \\
\text { California, facility. }\end{array}$ & $\begin{array}{l}\text { The fuel cell system at Xilinx } \\
\text { reduces } \mathrm{CO}_{2} \text { emissions by an } \\
\text { estimated } 2,700,000 \text { lbs. per } \\
\text { year. }{ }^{85}\end{array}$ \\
\hline 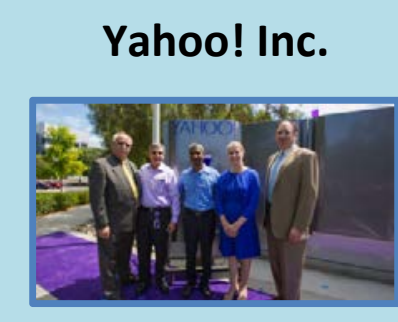 & $\begin{array}{l}\text { Yahoo! installed 1-MW of Bloom } \\
\text { Energy fuel cells in } 2014 \text { to } \\
\text { generate power at its Sunnyvale, } \\
\text { California, headquarters. The fuel } \\
\text { cells reduce the facility's grid } \\
\text { energy use by } 33 \% \text {. }\end{array}$ & $\begin{array}{l}\text { Yahoo! is reducing its } \mathrm{CO}_{2} \\
\text { emissions in Sunnyvale annually } \\
\text { by an estimated } 2,700,000 \text { lbs. }^{86}\end{array}$ \\
\hline
\end{tabular}




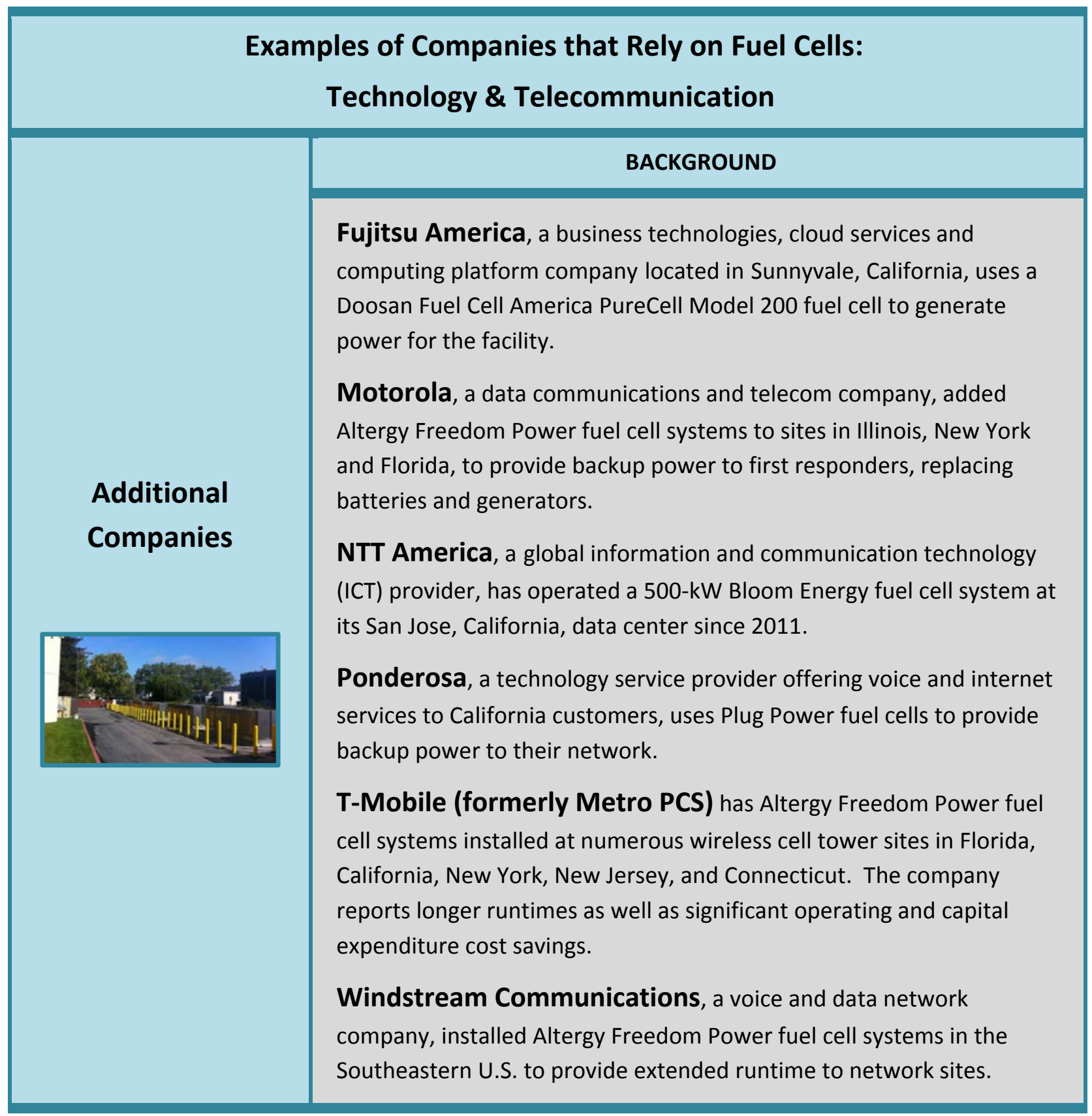




\section{Financial Services}

According to the U.S. Department of Energy, there are about 3 million data centers in the United States, consuming 100 billion $\mathrm{kWh}$ of electricity a year and comprising more than $2 \%$ of all U.S. electricity use. ${ }^{87}$ Ongoing strong growth in the data center market could strain existing grid resources and impact power reliability, with power outages costing data centers over $\$ 7,000$ per minute, and more than half a million dollars per occurrence. ${ }^{88}$

Fuel cells can help to mitigate this problem. Financial services companies and banks are trusting fuel cells to generate high quality, reliable power for data centers and mission critical applications. Resilient, onsite fuel cells are able to provide assured power at a high efficiency, helping meet sustainability goals while ensuring financial transactions and operations will continue, regardless of circumstances.

\begin{tabular}{|c|c|c|}
\hline \multicolumn{3}{|c|}{$\begin{array}{l}\text { Examples of Companies that Rely on Fuel Cells: } \\
\qquad \text { Financial Services }\end{array}$} \\
\hline COMPANY & BACKGROUND & UPDATE \\
\hline Bank of America & $\begin{array}{l}\text { In 2011, Bank of America } \\
\text { installed a 500-kW Bloom } \\
\text { Energy fuel cell system at one of } \\
\text { its largest call centers in } \\
\text { Calabasas, California. } \\
\text { Bloom Energy and Bank of } \\
\text { America Merrill Lynch also have } \\
\text { teamed to offer a leasing } \\
\text { program for business customers } \\
\text { to finance Bloom Energy fuel } \\
\text { cell systems. The program } \\
\text { streamlines customer } \\
\text { deployment and eliminates the } \\
\text { need for an upfront capital } \\
\text { investment. }\end{array}$ & $\begin{array}{l}\text { The fuel cell in Calabasas has } \\
\text { resulted in an estimated } \\
1,300,000 \mathrm{lbs} \text {. of } \mathrm{CO}_{2} \text { reductions } \\
\text { per year. }{ }^{89}\end{array}$ \\
\hline Franklin Templeton & $\begin{array}{l}\text { Investment firm Franklin } \\
\text { Templeton has operated a 1- } \\
\text { MW Bloom Energy fuel cell } \\
\text { system at its San Mateo } \\
\text { California, site since } 2011 \text {. }\end{array}$ & $\begin{array}{l}\text { The fuel cell at Franklin } \\
\text { Templeton has resulted in an } \\
\text { estimated } 2,700,000 \mathrm{lbs} \text {. of } \mathrm{CO}_{2} \\
\text { reductions annually. }{ }^{90}\end{array}$ \\
\hline
\end{tabular}




\begin{tabular}{|c|c|c|}
\hline \multicolumn{3}{|c|}{$\begin{array}{l}\text { Examples of Companies that Rely on Fuel Cells: } \\
\qquad \text { Financial Services }\end{array}$} \\
\hline COMPANY & BACKGROUND & UPDATE \\
\hline JPMorgan Chase & $\begin{array}{l}\text { Financial services company } \\
\text { JPMorgan Chase installed a } \\
\text { 500-kW Bloom Energy fuel cell } \\
\text { system in } 2013 \text { to power its } \\
\text { Newark, Delaware, data center. }\end{array}$ & $\begin{array}{l}\text { The fuel cell reduces an } \\
\text { estimated } 3,000,000 \mathrm{lbs} \text {. of } \mathrm{CO}_{2} \\
\text { per year. }\end{array}$ \\
\hline $\begin{array}{l}\text { Morgan Stanley } \\
\text { - }\end{array}$ & $\begin{array}{l}\text { Financial services company } \\
\text { Morgan Stanley installed a } \\
250-k W \text { Bloom Energy fuel cell } \\
\text { to generate power at its } \\
\text { headquarters facility in } \\
\text { Purchase, New York, in } 2014 \text {. }\end{array}$ & $\begin{array}{l}\text { In 2016, Morgan Stanley } \\
\text { installed its second fuel cell } \\
\text { system, a } 750-k W \text { Bloom Energy } \\
\text { fuel cell, to supply power at its } \\
\text { global headquarters in New York } \\
\text { City. The fuel cell is located on a } \\
\text { rooftop setback on the eighth } \\
\text { floor. } \\
\text { The } 250-k W \text { fuel cell located in } \\
\text { Purchase, has led to an } \\
\text { estimated } 1,300,000 \text { lbs. of } \mathrm{CO}_{2} \\
\text { reductions per year. }{ }^{92}\end{array}$ \\
\hline & \multicolumn{2}{|c|}{ BACKGROUND } \\
\hline $\begin{array}{l}\text { Additional } \\
\text { Companies }\end{array}$ & \multicolumn{2}{|c|}{$\begin{array}{l}\text { First National Bank of Omaha was the first U.S. company to use } \\
\text { fuel cell technology as its primary power source. The Doosan Fuel Cell } \\
\text { America system was installed in } 1999 \text { to provide primary power to the } \\
\text { bank's Omaha, Nebraska, data center. In its first } 10 \text { years of operation, } \\
\text { the fuel cell provided } 89,000 \text { hours of operation and reduced heating } \\
\text { bills by more than } \$ 1 \text { million. Availability of the fuel cell system } \\
\text { exceeded } 99.9999 \% \text {. } \\
\text { In } 2013 \text {, First National Bank of Omaha replaced its first fuel cell, which } \\
\text { provided power to its data center for } 14 \text { years, with a new } 400-k W \\
\text { Doosan Fuel Cell America fuel cell system. }\end{array}$} \\
\hline
\end{tabular}




\section{Real Estate}

Since fuel cells are scalable to multi-megawatt sized units, the technology is showing up in larger facilities, like shopping centers, office parks and towers, and multi-use retail/residential buildings, as well as the data centers, corporate campuses, sports arenas, and warehouses described above. These fuel cells keep the buildings up and running by providing power and heat, even when bad weather hits, and do so while lowering carbon emissions and providing energy cost savings.

\begin{tabular}{|c|c|c|}
\hline \multicolumn{3}{|c|}{$\begin{array}{l}\text { Examples of Companies that Rely on Fuel Cells: } \\
\qquad \text { Real Estate }\end{array}$} \\
\hline COMPANY & BACKGROUND & UPDATE \\
\hline $\begin{array}{c}\text { Doosan Fuel Cell America fuel } \\
\text { cell system } t \text { The Octagon in } \\
\text { New York Cityl }\end{array}$ & $\begin{array}{l}\text { Architectural firm Becker + } \\
\text { Becker has incorporated fuel } \\
\text { cells into several of its projects } \\
\text { including: } \\
\text { In 2010, a 400-kW unit from } \\
\text { Doosan Fuel Cell America was } \\
\text { installed to supply power and } \\
\text { heat at the } 360 \text { State Street } \\
\text { retail and residential tower in } \\
\text { New Haven, Connecticut. The } \\
\text { fuel cell also supplies power to } \\
\text { electric vehicle chargers at the } \\
\text { building. } \\
\text { In } 2011 \text {, a } 400-k W \text { Doosan Fuel } \\
\text { Cell America system was } \\
\text { installed for Bentall Kennedy in } \\
\text { The Octagon, a historic } \\
\text { property in New York City that } \\
\text { was converted to apartments. } \\
\text { In } 2015 \text {, a } 400-k W \text { Doosan Fuel } \\
\text { Cell America system was } \\
\text { installed at } 777 \text { Main Street in } \\
\text { Hartford, Connecticut, to } \\
\text { supply power and heat at the } \\
\text { mixed use apartment building. }\end{array}$ & $\begin{array}{l}\text { In July } 2015, \text { Connecticut's } \\
\text { Public Utilities Regulatory } \\
\text { Authority approved } \\
\text { submetering of tenants at } \\
777 \text { Main Street. This allows } \\
\text { the facility to sell electricity, } \\
\text { which is generated onsite by } \\
\text { fuel cells, to the building's } \\
\text { tenants. } \\
\text { Customer Bentall Kennedy } \\
\text { reports that, after Hurricane } \\
\text { Sandy, when buildings around } \\
\text { The Octagon were without } \\
\text { electricity and heat, property } \\
\text { management at The Octagon } \\
\text { managed to reroute its fuel cell } \\
\text { to provide both working water } \\
\text { pumps and elevators for its } \\
\text { residents. }{ }^{94}\end{array}$ \\
\hline
\end{tabular}




\begin{tabular}{|c|c|c|}
\hline \multicolumn{3}{|c|}{$\begin{array}{l}\text { Examples of Companies that Rely on Fuel Cells: } \\
\qquad \text { Real Estate }\end{array}$} \\
\hline COMPANY & BACKGROUND & UPDATE \\
\hline Hines/LPL Financial & $\begin{array}{l}\text { In 2013, real estate company } \\
\text { Hines installed a 300-kW } \\
\text { Bloom Energy fuel cell system } \\
\text { at a San Diego, California, } \\
\text { office building leased to } \\
\text { tenant LPL Financial. The } \\
\text { 13-story office tower, which is } \\
\text { the largest net-zero energy } \\
\text { commercial office building in } \\
\text { the U.S., is LPL Financial's } \\
\text { headquarters facility. }\end{array}$ & $\begin{array}{l}\text { The project at Hines has } \\
\text { resulted in an estimated } \\
820,000 \mathrm{lbs} \text {. of } \mathrm{CO}_{2} \text { reductions } \\
\text { per year. }{ }^{95}\end{array}$ \\
\hline $\begin{array}{c}\text { JMB Realty/ } \\
\text { Constellation Place }\end{array}$ & $\begin{array}{l}\text { A 400-kW Bloom Energy fuel } \\
\text { cell system was installed in } \\
2011 \text { to power one-third of } \\
\text { JMB Realty's Constellation } \\
\text { Place office tower in Century } \\
\text { City, California. }\end{array}$ & $\begin{array}{l}\mathrm{JMB} \text { is reducing its } \mathrm{CO}_{2} \\
\text { emissions by an estimated } \\
1,000,000 \mathrm{lbs} \text {. of } \mathrm{CO}_{2} \text { reductions } \\
\text { annually. }{ }^{96}\end{array}$ \\
\hline $\begin{array}{l}\text { The Ratkovich Co./The } \\
\text { Alhambra }\end{array}$ & $\begin{array}{l}\text { A 500-kW Bloom Energy fuel } \\
\text { cell generates over } 25 \% \text { of the } \\
\text { electricity used at The } \\
\text { Alhambra office park in } \\
\text { Alhambra, California. }\end{array}$ & $\begin{array}{l}\text { In } 2013 \text {, the Bloom Energy } \\
\text { system saved The Alhambra } \\
\text { more than } \$ 200,000 \text { in } \\
\text { electrical costs, over } 10 \% \text { of } \\
\text { the total annual electrical } \\
\text { budget. }^{97}\end{array}$ \\
\hline
\end{tabular}




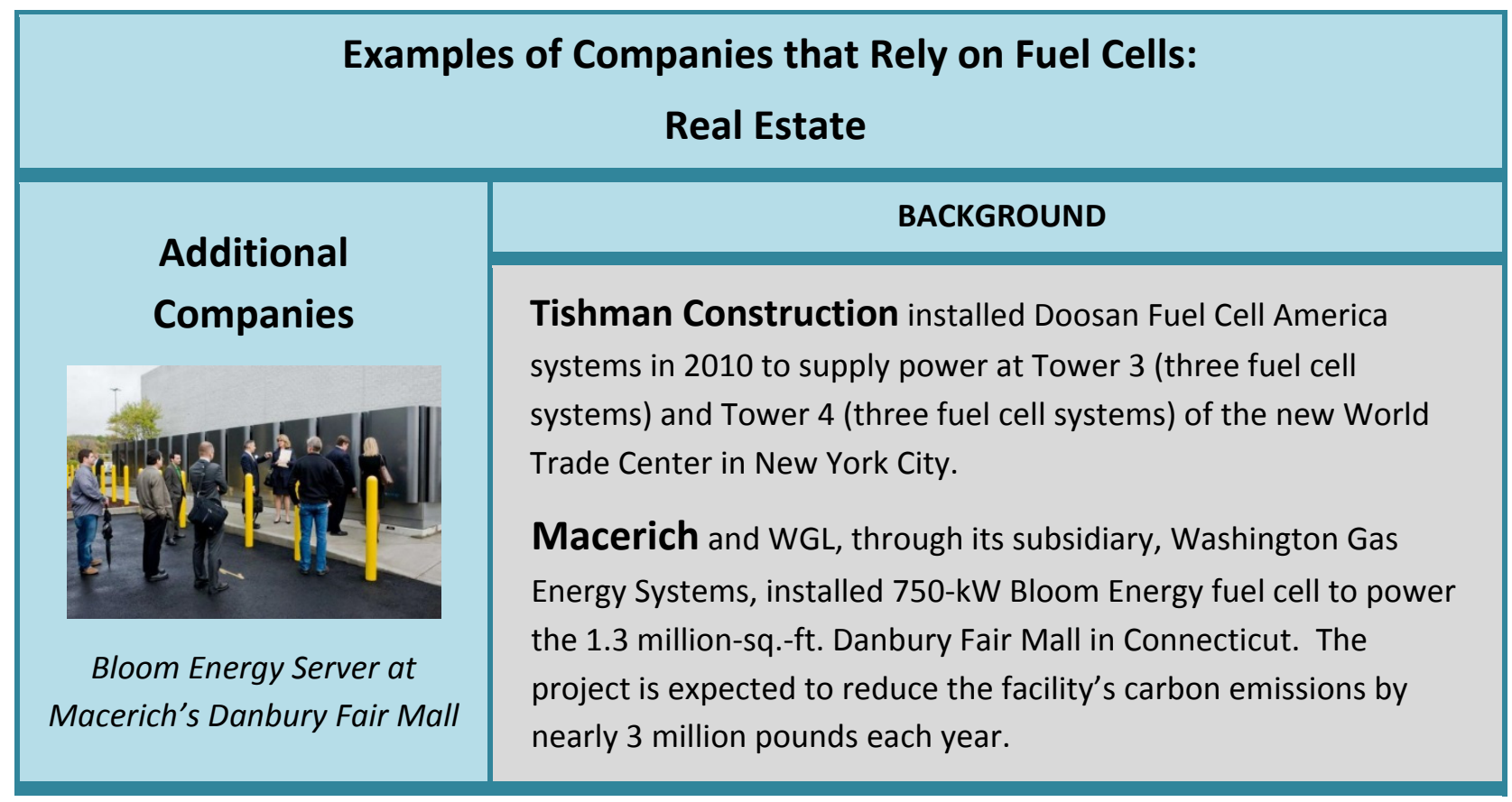




\section{Healthcare \& Biotechnology}

Reliability is critical to healthcare facilities, to keep hospitals and treatment facilities up and running, and protecting life-saving vaccines, research and above all, patients. Onsite fuel cell power generation keeps essential services operating, even when other sites lack power.

In addition to onsite power supply, fuel cells can provide additional benefits. A fuel cell's byproduct heat can be recovered for use in facility heating, provision of hot water and, when run through an absorption chiller, for facility cooling.

Fuel cells also provide a bonus in a hospital setting since they operate quietly, producing about 60-70 decibels of sound (the typical level of a conversation) allowing patients to heal without the intrusion of unwanted noise.

Like corporations, healthcare and biotech companies use fuel cells to generate power at their corporate and research campuses. Fuel cells are helping both hospitals and biotech facilities meet emission reduction goals while saving on energy and water costs.

\begin{tabular}{|c|c|c|}
\hline \multicolumn{3}{|c|}{$\begin{array}{l}\text { Examples of Companies that Rely on Fuel Cells: } \\
\text { Healthcare \& Biotechnology }\end{array}$} \\
\hline COMPANY & BACKGROUND & UPDATE \\
\hline $\begin{array}{c}\text { BD (Becton, } \\
\text { Dickinson \& } \\
\text { Company) }\end{array}$ & $\begin{array}{l}\text { In 2011, medical technology } \\
\text { company BD (Becton, Dickinson } \\
\text { \& Company) installed an 800-kW } \\
\text { Bloom Energy fuel cell system to } \\
\text { generate power at its BD } \\
\text { BioSciences facility in San Jose, } \\
\text { California. }\end{array}$ & $\begin{array}{l}\text { The fuel cell system at } \mathrm{BD} \\
\text { Biosciences has resulted in an } \\
\text { estimated } 2,100,000 \mathrm{lbs} \text {. of } \\
\mathrm{CO}_{2} \text { reductions per year. }{ }^{98}\end{array}$ \\
\hline
\end{tabular}




\begin{tabular}{|c|c|c|}
\hline \multicolumn{3}{|c|}{$\begin{array}{l}\text { Examples of Companies that Rely on Fuel Cells: } \\
\text { Healthcare \& Biotechnology }\end{array}$} \\
\hline COMPANY & BACKGROUND & UPDATE \\
\hline $\begin{array}{l}\text { Fuel cell system at the Irvine J\&J } \\
\text { ASP facility }\end{array}$ & $\begin{array}{l}\text { In } 2015 \text {, Johnson \& Johnson } \\
\text { Advanced Sterilization Products } \\
\text { (ASP) installed a 500-kW Bloom } \\
\text { Energy Server to provide } 25 \% \text { of } \\
\text { the Irvine, California, facility's } \\
\text { daily energy consumption. The } \\
\text { company anticipates that the fuel } \\
\text { cells will save an estimated } \\
\$ 10 \text { million over the } 20 \text { year life } \\
\text { of the project. } \\
\text { Also in } 2015 \text {, Johnson \& } \\
\text { Johnson's cardiac catheters } \\
\text { company Biosense Webster, } \\
\text { added a } 375-k W \text { Bloom Energy } \\
\text { fuel cell to supply power at its } \\
\text { Irwindale, California, site. }\end{array}$ & $\begin{array}{l}\text { J\&J reports that its two fuel } \\
\text { cell systems supply } 2 \% \text { of the } \\
\text { energy used by the company } \\
\text { worldwide, providing } 26 \\
\text { terajoules of energy in } 2015 .^{99} \\
\text { The Irvine project has led to } \\
\text { an estimated } 1,300,000 \mathrm{lbs} \text {. of } \\
\mathrm{CO}_{2} \text { reductions annually, while } \\
\text { the Irwindale project has } \\
\text { resulted in an estimated } \\
1,000,000 \text { lbs. }\end{array}$ \\
\hline 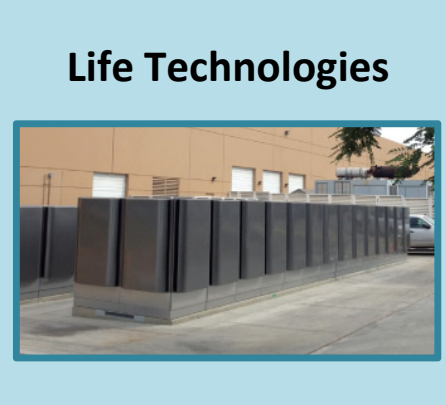 & $\begin{array}{l}\text { Biotech company Life } \\
\text { Technologies installed 1-MW of } \\
\text { Bloom Energy fuel cell systems at } \\
\text { its California facilities in Carlsbad } \\
\text { (2012) and Pleasanton (2013). }\end{array}$ & $\begin{array}{l}\text { The two installations, totaling } \\
2 \mathrm{MW} \text {, reduce } \mathrm{CO}_{2} \text { emissions } \\
\text { by an estimated } 5,400,000 \mathrm{lbs} \text {. } \\
\text { annually. }{ }^{101} \\
\text { Bloom Energy features a Life } \\
\text { Technologies customer profile } \\
\text { video on their website. }{ }^{102}\end{array}$ \\
\hline
\end{tabular}




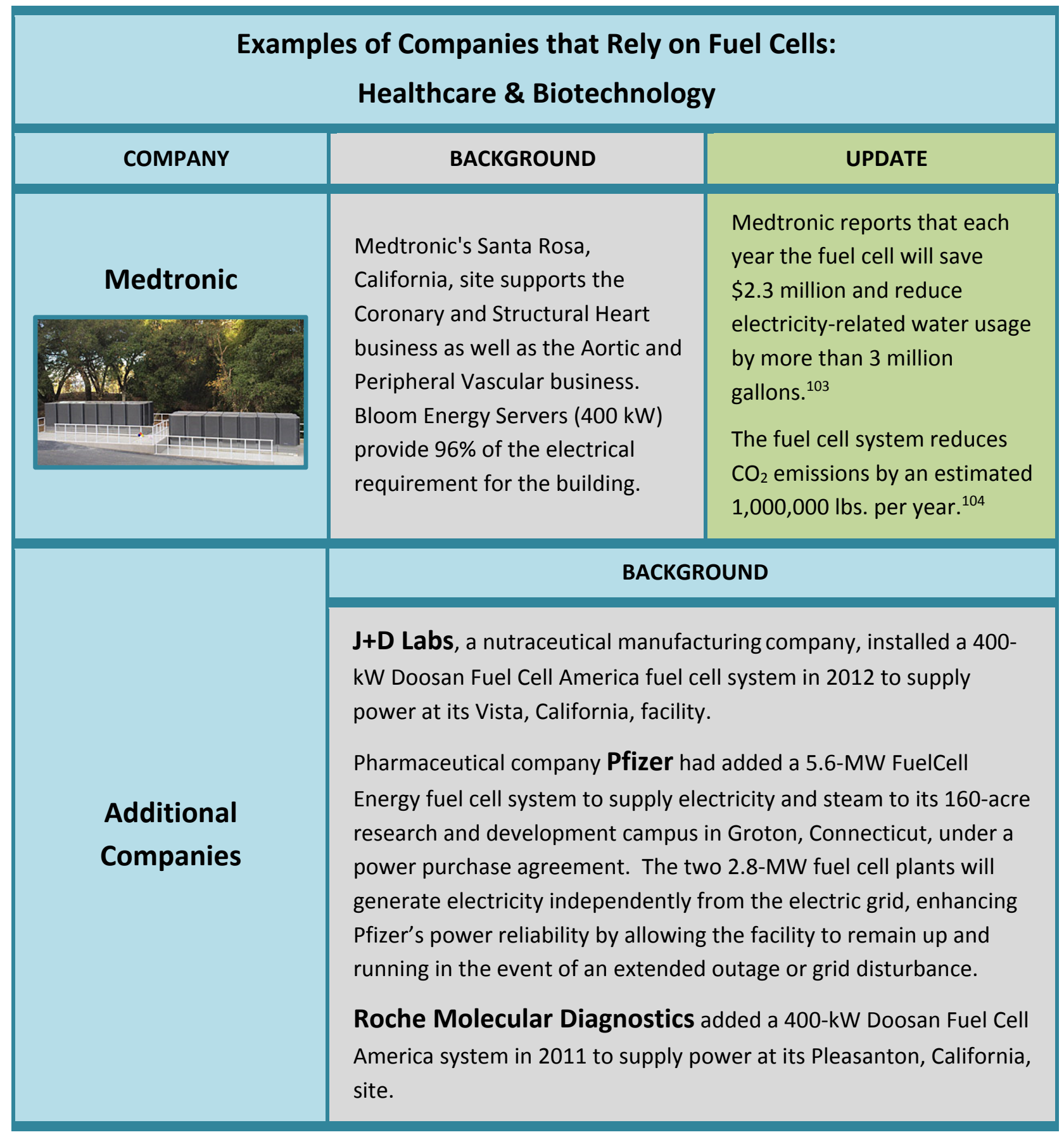




\begin{tabular}{|c|c|c|c|c|}
\hline Exam & $\begin{array}{l}\text { s of Companies that Rely } \\
\text { Healthcare Facilities }\end{array}$ & uel Cell & & \\
\hline HEALTHCARE FACILITY & BACKGROUND & \multicolumn{3}{|c|}{ UPDATE } \\
\hline 5ilim & $\begin{array}{l}\text { Prime Healthcare's Chino Valley } \\
\text { Medical Center in Ontario, } \\
\text { California, generates power } \\
\text { using a 600-kW Bloom Energy } \\
\text { Server. }\end{array}$ & \multicolumn{3}{|c|}{$\begin{array}{l}\text { The fuel cell at Chino Valley } \\
\text { Medical Center reduces } \mathrm{CO}_{2} \\
\text { emissions annually by an } \\
\text { estimated } 1,600,000 \text { lbs. }^{105}\end{array}$} \\
\hline & $\begin{array}{l}\text { Kaiser Permanente has operates } \\
\text { Bloom Energy fuel cells at seven } \\
\text { of its California facilities, } \\
\text { cumulatively totaling } 4.3 \mathrm{MW} \text { of } \\
\text { power generation. }\end{array}$ & \multicolumn{3}{|c|}{$\begin{array}{l}\text { Kaiser's fleet of fuel cells are } \\
\text { saving an estimated } \\
11,800,000 \mathrm{lbs} \text {. of } \mathrm{CO}_{2} \\
\text { emissions per year. }{ }^{106}\end{array}$} \\
\hline \multirow[b]{2}{*}{ St. Francis Hospital } & \multirow{6}{*}{$\begin{array}{l}\text { Saint Francis Hospital and } \\
\text { Medical Center, Main Campus in } \\
\text { Hartford, Connecticut, installed } \\
\text { a 400-kW Doosan Fuel Cell } \\
\text { America PureCell system in } \\
\text { 2013, replacing a 200-kW } \\
\text { PureCell that had been in } \\
\text { operation since 2003. The fuel } \\
\text { cell provides continuous-duty } \\
\text { baseload operation with back- } \\
\text { up power for non-emergency } \\
\text { electrical loads and heat } \\
\text { recovery for space heating and } \\
\text { domestic hot water. } \\
\text { St. Francis' Mt. Sinai Rehab } \\
\text { Hospital Campus, located in } \\
\text { New Haven, Connecticut, also } \\
\text { utilizes a } 400-k W \text { PureCell fuel } \\
\text { cell system from Doosan Fuel } \\
\text { Cell America. }\end{array}$} & & & \\
\hline & & $\begin{array}{l}\text { Saint Francis } \\
\text { Hospital }\end{array}$ & $\begin{array}{l}\text { Emissions } \\
\text { Reduction }\end{array}$ & $\begin{array}{l}\text { Equivalent } \\
\text { "Green" Benefit }\end{array}$ \\
\hline \multirow{4}{*}{ 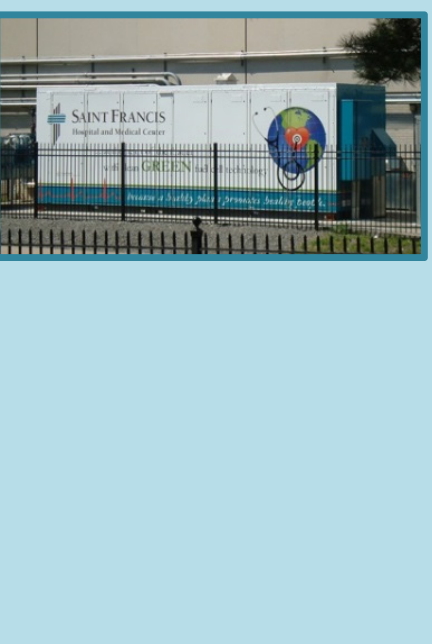 } & & $\mathrm{CO}_{2}$ Emissions & $537 \mathrm{MT}+$ & \begin{tabular}{|l} 
Planting 124 \\
acres of trees
\end{tabular} \\
\hline & & $\mathrm{NO}_{\mathrm{x}}$ Emissions & $1.26 \mathrm{MT}$ & $\begin{array}{l}\text { Taking } 72 \text { cars } \\
\text { off the road }\end{array}$ \\
\hline & & Water Saved * & $1.4 \mathrm{MG} \mathrm{t}$ & \begin{tabular}{|l} 
Saving enough \\
water to fill $\sim 2.2$ \\
Olympic pools
\end{tabular} \\
\hline & & & & \\
\hline
\end{tabular}




\begin{tabular}{|c|c|c|}
\hline \multicolumn{3}{|c|}{$\begin{array}{l}\text { Examples of Companies that Rely on Fuel Cells: } \\
\text { Healthcare \& Biotechnology }\end{array}$} \\
\hline COMPANY & BACKGROUND & UPDATE \\
\hline St. Helena Hospital & $\begin{array}{l}\text { One } 400 \text { kW, continuous-duty } \\
\text { Doosan Fuel Cell America } \\
\text { PureCell system was installed in } \\
2010 \text { at the St. Helena, California, } \\
\text { hospital campus, to generate } \\
\text { power for the facility. The } \\
\text { PureCell Model } 400 \text { additionally } \\
\text { provides heat recovery for space } \\
\text { heating and domestic hot water. }\end{array}$ & $\begin{array}{l}\text { The hospital conserves } \\
1.2 \text { million gallons of water } \\
\text { while achieving an energy } \\
\text { savings of } \$ 170,000 \text { per } \\
\text { year. }^{107}\end{array}$ \\
\hline $\begin{array}{c}\text { Sutter Health/Sutter } \\
\text { Santa Rosa Regional } \\
\text { Hospital }\end{array}$ & $\begin{array}{l}\text { Sutter Santa Rosa Regional } \\
\text { Hospital in Santa Rosa, California, } \\
\text { generates power using a } 375-k W \\
\text { Bloom Energy Server. The fuel cell } \\
\text { was installed in } 2014 \text {. }\end{array}$ & $\begin{array}{l}\text { The project at Sutter Health } \\
\text { achieves an estimated } \\
1,000,000 \text { lbs. of annual } \mathrm{CO}_{2} \\
\text { reductions. }{ }^{108}\end{array}$ \\
\hline $\begin{array}{l}\text { Veterans } \\
\text { Administration } \\
\text { Hospital }\end{array}$ & $\begin{array}{l}\text { The Veterans Administration (VA) } \\
\text { Hospital in Loma Linda, California, } \\
\text { operates an } 800-k W \text { Doosan Fuel } \\
\text { Cell America fuel cell system. The } \\
\text { PureCell Model } 400 \text { system } \\
\text { provides continuous power } \\
\text { generation with heat recovery for } \\
\text { space heating and domestic hot } \\
\text { water. }\end{array}$ & $\begin{array}{l}\text { The VA Hospital's Doosan fuel } \\
\text { cell system has an overall } \\
\text { efficiency averaging } 70 \% \text { and } \\
\text { provides } \mathrm{CO}_{2} \text { savings of } 705 \\
\text { metric tons per year, } \mathrm{NO}_{\mathrm{x}} \\
\text { savings of } 3.0 \text { metric tons per } \\
\text { year, and water savings of } \\
\sim 1 \text { million gallons per year. }{ }^{109}\end{array}$ \\
\hline
\end{tabular}




\begin{tabular}{l|l|}
$\begin{array}{c}\text { Additional Healthcare } \\
\text { Facilities }\end{array}$ & \multicolumn{1}{c|}{ BACKGROUND } \\
\hline & $\begin{array}{l}\text { Hartford Hospital in Hartford, Connecticut, installed a 1.4-MW } \\
\text { FuelCell Energy system in } 2013 \text { and the heat byproduct is to produce } \\
\text { steam and enhance efficiency. }\end{array}$ \\
\hline $\begin{array}{l}\text { The University of California Irvine Medical Center utilizes a } \\
\text { FuelCell Energy power plant at } \\
\text { Hartford Hospital }\end{array}$ & $\begin{array}{l}\text { 1.4 MW FuelCell Energy CHP fuel cell power plant that provides } \\
\text { exhaust absorption chiller to produce } 200 \text { tons of cooling. }\end{array}$ \\
\hline
\end{tabular}




\section{Entertainment \& Sports}

People love to be entertained, and to cheer on their favorite team, especially at live events. When power outages occur, the cheering can quickly turn to boos. In 2013, at Super Bowl XLVII in New Orleans, the Mercedes-Benz Superdome went dark for 34 minutes $^{110}$, leaving fans both in their seats in the stadium and watching at home, powerless.

To avoid a repeat performance, several stadiums and arenas in California have installed fuel cells to make sure operations continue running, despite any unforeseen outages. Television, movie, and news studios are also casting fuel cells to not only keep us entertained without interruption, but in case of emergency, to provide power for up-to-the-minute news alerts and public service announcements.

\section{Examples of Companies that Rely on Fuel Cells: \\ Entertainment \& Sports}

\begin{tabular}{|c|c|c|c|c|}
\hline COMPANY & BACKGROUND & \multicolumn{3}{|c|}{ UPDATE } \\
\hline \multirow{6}{*}{$\begin{array}{c}\text { Beacon Capital } \\
\text { Partners/News } \\
\text { Corp. }\end{array}$} & $\begin{array}{l}\text { In 2012, Beacon Capital Partners } \\
\text { installed a Doosan Fuel Cell } \\
\text { America fuel cell at its } \\
\text { headquarters at } 1211 \text { Avenue of } \\
\text { the Americas in New York to } \\
\text { produce power for their main } \\
\text { tenant, News Corporation, } \\
\text { supplying a major portion of the } \\
\text { power requirement for their }\end{array}$ & \multicolumn{3}{|c|}{$\begin{array}{l}\text { Beacon Capital reports minimal } \\
\text { outages and } 93 \% \text { availability of } \\
\text { the fuel cell. }{ }^{111}\end{array}$} \\
\hline & $\begin{array}{l}\text { television studios. The fuel cell } \\
\text { provides } 100 \% \text { of electric output }\end{array}$ & $\begin{array}{l}\text { Beacon Office } \\
\text { Building }\end{array}$ & $\begin{array}{l}\text { Emissions } \\
\text { Reduction }\end{array}$ & $\begin{array}{l}\text { Equivalent } \\
\text { "Green" Benefit }\end{array}$ \\
\hline & used by Fox News ( $24 \times 7), 25 \%$ of & $\mathrm{CO}_{2}$ Emissions & 600 MT & $\begin{array}{l}\text { Planting } 138 \\
\text { acres of trees }\end{array}$ \\
\hline & & $\mathrm{NO}_{\mathrm{x}}$ Emissions & 1.31 MT & $\begin{array}{l}\text { Taking } 75 \text { cars } \\
\text { of the road }\end{array}$ \\
\hline & $\begin{array}{l}\text { hot water output used in heating } \\
\text { months. It also provides }\end{array}$ & Water Saved & $1.4 \mathrm{MG}$ & $\begin{array}{l}\text { Saving enough } \\
\text { water to fill } 2.2 \\
\text { Olympic pools }\end{array}$ \\
\hline & $\begin{array}{l}\text { emergency power to lobby, } \\
\text { covered arcade, the lobby level } \\
\text { restaurant, and to an outdoor } \\
\text { Fox News ticker for news } \\
\text { updates and public service } \\
\text { announcements. }\end{array}$ & & & \\
\hline
\end{tabular}




\begin{tabular}{|c|c|c|}
\hline \multicolumn{3}{|c|}{$\begin{array}{l}\text { Examples of Companies that Rely on Fuel Cells: } \\
\text { Entertainment \& Sports }\end{array}$} \\
\hline COMPANY & BACKGROUND & UPDATE \\
\hline CBS Studios & $\begin{array}{l}\text { CBS Studio Center, which is } \\
\text { home to a production and office } \\
\text { facility with } 18 \text { sound stages, } \\
\text { uses } 1.2 \mathrm{MW} \text { of Doosan Fuel Cell } \\
\text { America fuel cells to meet } 40 \% \\
\text { of its power needs. CBS } \\
\text { Television City also uses a } \\
1.2-\mathrm{MW} \text { Doosan fuel cell system } \\
\text { to provide } 60 \% \text { of the power to } \\
\text { the site's eight sound stages and } \\
\text { office space. }\end{array}$ & $\begin{array}{l}\text { CBS reports that, "In } 2014 \text { four } \\
\text { passive photovoltaic arrays and } \\
\text { six fuel cells generated } \\
22,148,313 \text { kWh of electricity at } \\
\text { the CBS-Television City and } \\
\text { Studio Center facilities near Los } \\
\text { Angeles, California. Since the } \\
\text { CBS studios are frequently } \\
\text { leased to outside production } \\
\text { companies, these third parties } \\
\text { are able to avoid greenhouse } \\
\text { gas emissions through the use } \\
\text { of CBS assets." } 112\end{array}$ \\
\hline Disney Pixar & $\begin{array}{l}\text { A 1-MW Bloom Energy fuel cell } \\
\text { produces power at Disney's Pixar } \\
\text { Animation Studios in Emeryville, } \\
\text { California. }\end{array}$ & $\begin{array}{l}\text { The Disney Pixar fuel cells have } \\
\text { annually eliminated an } \\
\text { estimated } 2,700,000 \mathrm{lbs} \text {. of } \\
\mathrm{CO}_{2} .{ }^{113}\end{array}$ \\
\hline $\begin{array}{c}\text { DreamWorks } \\
\text { Animation }\end{array}$ & $\begin{array}{l}\text { A } 750-k W \text { Bloom Energy fuel cell } \\
\text { system is installed at a } \\
\text { DreamWorks facility in Glendale, } \\
\text { California. Annually, the system } \\
\text { provides more than } 6 \text { million } \\
\text { kWh electricity of for the six } \\
\text { acre campus and } 460,000 \text {-sq.-ft. } \\
\text { of office space. }\end{array}$ & $\begin{array}{l}\text { The project has resulted in an } \\
\text { estimated } 2,000,000 \mathrm{lbs} \text {. of } \mathrm{CO}_{2} \\
\text { reductions per year. }{ }^{114}\end{array}$ \\
\hline
\end{tabular}




\begin{tabular}{|c|c|c|}
\hline \multicolumn{3}{|c|}{$\begin{array}{l}\text { Examples of Companies that Rely on Fuel Cells: } \\
\text { Entertainment \& Sports }\end{array}$} \\
\hline COMPANY & BACKGROUND & UPDATE \\
\hline Honda Center & $\begin{array}{l}\text { The Honda Center, located in } \\
\text { Anaheim, California, uses a } 750 \text { - } \\
\text { kW Bloom Energy Server that } \\
\text { provides more than half of the } \\
\text { power required by the sports } \\
\text { and entertainment facility each } \\
\text { year. The venue is home to the } \\
\text { Anaheim Ducks of the National } \\
\text { Hockey League. }\end{array}$ & $\begin{array}{l}\text { The fuel cell at Honda Center } \\
\text { provides an estimated } \\
2,000,000 \text { lbs. reduction of } \mathrm{CO}_{2} \\
\text { emissions per year. }{ }^{115}\end{array}$ \\
\hline NBCUniversal & $\begin{array}{l}\text { In April 2011, NBCUniversal } \\
\text { installed } 20 \mathrm{~kW} \text { of fuel cells at the } \\
\text { production kitchen at Universal } \\
\text { Studios Hollywood. The natural } \\
\text { gas-powered fuel cells supplied } \\
\text { both electricity and hot water to } \\
\text { the food production kitchens. }\end{array}$ & $\begin{array}{l}\text { In April 2016, NBCUniversal } \\
\text { installed a 250-kW Bloom Energy } \\
\text { server at a new NBC } 7 \text { San Diego/ } \\
\text { KNSD two-story, 52,000 sq.-ft. } \\
\text { state-of-the-art broadcast } \\
\text { facility. }{ }^{116}\end{array}$ \\
\hline $\begin{array}{l}\text { SAP Center/Shark's } \\
\text { Ice }\end{array}$ & $\begin{array}{l}\text { Sharks Sports \& Entertainment } \\
\text { (SSE), owner of the SAP Center in } \\
\text { San Jose, California, installed a } \\
400-k W \text { Bloom Energy Server at } \\
\text { the sports and entertainment } \\
\text { facility in 2012. SAP Center is } \\
\text { home to the San Jose Sharks of } \\
\text { the National Hockey League. } \\
\text { Also in 2012, SSE installed a } \\
500-k W \text { Bloom Energy Server at } \\
\text { Shark's Ice, a public recreational } \\
\text { ice facility owned by the City of } \\
\text { San Jose and managed by SSE. }\end{array}$ & $\begin{array}{l}\text { The project at SAP Center has } \\
\text { saved an estimated } 1,000,000 \\
\text { Ibs. in } \mathrm{CO}_{2} \text { emissions per year. } \\
\text { The project at Shark's Ice has } \\
\text { led to an annual estimated } \\
\text { reduction of } 1,300,000 \text { lbs. of } \\
\mathrm{CO}_{2}{ }^{117}\end{array}$ \\
\hline
\end{tabular}




\begin{tabular}{|c|c|c|}
\hline \multicolumn{3}{|c|}{$\begin{array}{c}\text { Examples of Companies that Rely on Fuel Cells: } \\
\text { Entertainment \& Sports }\end{array}$} \\
\hline \multicolumn{1}{|c|}{ BACKGROUND } & \multicolumn{1}{|c|}{ UPDATE } \\
\hline COMPANY & \multicolumn{1}{|c|}{$\begin{array}{l}\text { In November 2015, AEG/Staples } \\
\text { Center, a sports and } \\
\text { entertainment complex in Los } \\
\text { Angeles, California, installed a } \\
500-k W \text { Bloom Energy server to } \\
\text { provide } 25 \% \text { of the facility's } \\
\text { energy. }{ }^{118}\end{array}$} & $\begin{array}{l}\text { Bloom Energy features a Staples } \\
\text { Center customer profile video } \\
\text { on their website. }{ }^{119}\end{array}$ \\
\hline
\end{tabular}




\section{Hotels}

Hotels were among the first businesses to try out fuel cells, implementing early demonstration units more than two decades ago, beginning in 1992 when a Hyatt Hotel used a demonstration 200-kW Doosan Fuel Cell America fuel cell to meet $20 \%$ of the hotel's power needs, with waste heat from the process used to heat water for guests and for the laundry.

Since that time, hotels located in California, New Jersey, New York, and Washington, have utilized fuel cells including: Double Tree Inn, Sheraton, Westin, Hilton, and the Mohegan Sun Casino and Hotel.

After more than a decade, these early fuel cells are no longer in operation. But in late 2015, Hyatt added a Bloom Energy fuel cell to its energy portfolio to supply onsite power and reduce carbon emissions.

\begin{tabular}{|c|c|c|}
\hline \multicolumn{3}{|c|}{$\begin{array}{l}\text { Examples of Companies that Rely on Fuel Cells: } \\
\qquad \text { Hotels }\end{array}$} \\
\hline COMPANY & BACKGROUND & UPDATE \\
\hline Hyatt Hotels & $\begin{array}{l}\text { On December 30, 2015, Hyatt } \\
\text { installed a 500-kW Bloom Energy } \\
\text { Server at the Hyatt Regency } \\
\text { Greenwich in Connecticut. The } \\
\text { fuel cell provides up to } 75 \% \text { of } \\
\text { the hotel's energy load, } \\
\text { generating significant cost } \\
\text { savings and reducing carbon } \\
\text { emissions by } 40 \% \text { compared to } \\
\text { electricity purchased from the } \\
\text { grid. }\end{array}$ & $\begin{array}{l}\text { Hyatt reports that the company } \\
\text { has been looking at innovative } \\
\text { energy technologies for some } \\
\text { time. } \\
\text { The company already has solar } \\
\text { photovoltaic and solar thermal } \\
\text { installations and fuel cells were } \\
\text { an innovative solution that the } \\
\text { company wanted to try. }{ }^{120} \\
\text { The fuel cell project is reducing } \\
\mathrm{CO}_{2} \text { emissions by an estimated } \\
1,800,000 \text { lbs. annually. }{ }^{121}\end{array}$ \\
\hline
\end{tabular}




\section{Transportation}

Major automakers are investing in fuel cells, and today, customers in California and other parts of the world are able to buy or lease fuel cell vehicles from several, with more entering the marketplace by the end of this year and next. These car manufacturers are also using fuel cells to help move the parts to build many other vehicles, with fuel cell-powered forklifts operating in automotive manufacturing plants around the country. This began more than ten years ago, in 2005, with General Motors (GM), testing 19 forklifts powered by Hydrogenics fuel cells at its Oshawa, Canada, car assembly plant.

Today, BMW, Honda, Mercedes-Benz, and Volkswagen all use fuel cell-powered forklifts at assembly and manufacturing facilities. This transportation section also covers logistics and delivery companies, railroads, and features a spotlight on a company utilizing fuel cell-powered mobile lighting to help repair crews fix the ferry dock at Alcatraz Island.

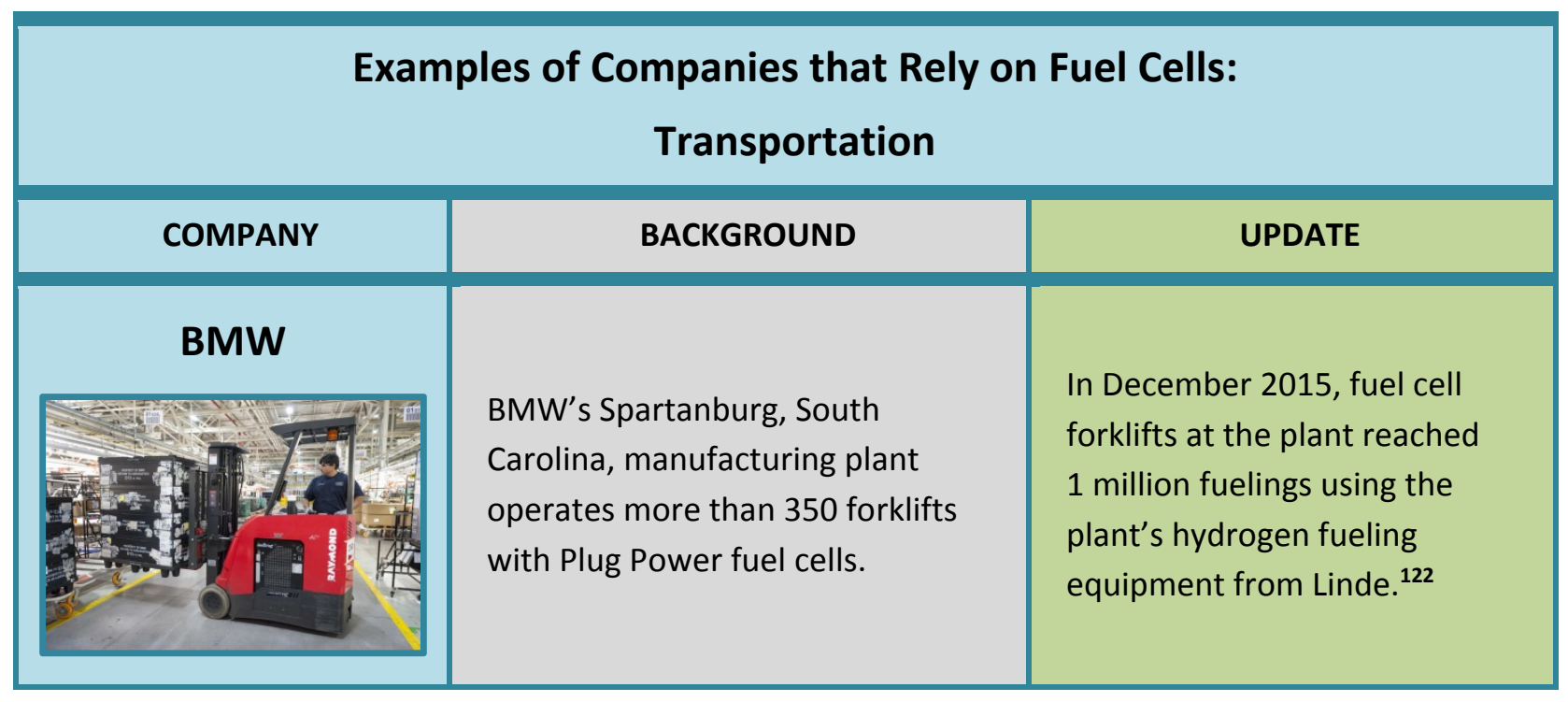




\begin{tabular}{|c|c|c|}
\hline \multicolumn{3}{|c|}{$\begin{array}{c}\text { Examples of Companies that Rely on Fuel Cells: } \\
\qquad \text { Transportation }\end{array}$} \\
\hline COMPANY & BACKGROUND & UPDATE \\
\hline $\begin{array}{l}\text { Bloom Energy fuel cell system } \\
\text { at a FedEx site }\end{array}$ & $\begin{array}{l}\text { FedEx installed a 500-kW Bloom } \\
\text { Energy Server in } 2010 \text { to generate } \\
\text { power at an Oakland, California, } \\
\text { hub. In 2014, a } 400-k W \text { fuel cell } \\
\text { system was added to a FedEx site } \\
\text { in Rialto, California. } \\
\text { FedEx also operates } 40 \text { fuel cell- } \\
\text { powered forklifts in Springfield, } \\
\text { Missouri, and is demonstrating } \\
15 \text { fuel cell-powered baggage tow } \\
\text { tractors at Memphis Airport in a } \\
\text { DOE-sponsored project. Plug } \\
\text { Power supplied fuel cell systems } \\
\text { for both deployments. FedEx will } \\
\text { demonstrate } 20 \text { fuel cell } \\
\text { extended-range battery electric } \\
\text { delivery vehicles in California and } \\
\text { Tennessee in another DOE- } \\
\text { sponsored project using Plug } \\
\text { Power fuel cells. }\end{array}$ & $\begin{array}{l}\text { The FedEx Oakland site tests } \\
\text { and implements cutting-edge } \\
\text { technologies that set } \\
\text { standards for other FedEx } \\
\text { locations and airlines. } \\
\text { Oakland Hub Director, Robin } \\
\text { Van Galder, reports that the } \\
\text { site's solar and fuel cell } \\
\text { resources are providing } 47 \% \\
\text { of of the facility's energy. }{ }^{123,} \\
\text { The Oakland and Rialto } \\
\text { projects estimated to reduce } \\
\mathrm{CO}_{2} \text { emissions by a combined } \\
2,400,000 \text { lbs. per year. }{ }^{124}\end{array}$ \\
\hline 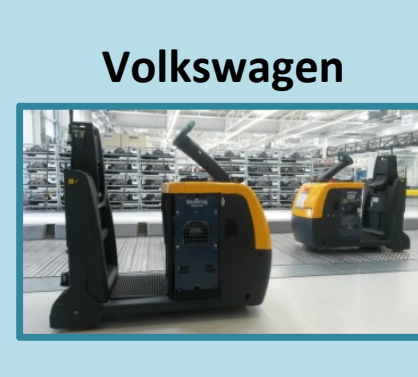 & $\begin{array}{l}\text { Volkswagen operates } 45 \text { forklifts } \\
\text { powered by Plug Power fuel cells } \\
\text { at its Chattanooga, Tennessee, } \\
\text { manufacturing facility. }\end{array}$ & $\begin{array}{l}\text { VW also uses Plug Power } \\
\text { GenDrive fuel cells to power } \\
\text { forklifts at its Kassel, Germany, } \\
\text { facility and is trialing a fuel cell- } \\
\text { powered Linde forklift at its } \\
\text { Dusseldorf facility that } \\
\text { assembles Sprinter vans. }{ }^{125}\end{array}$ \\
\hline
\end{tabular}




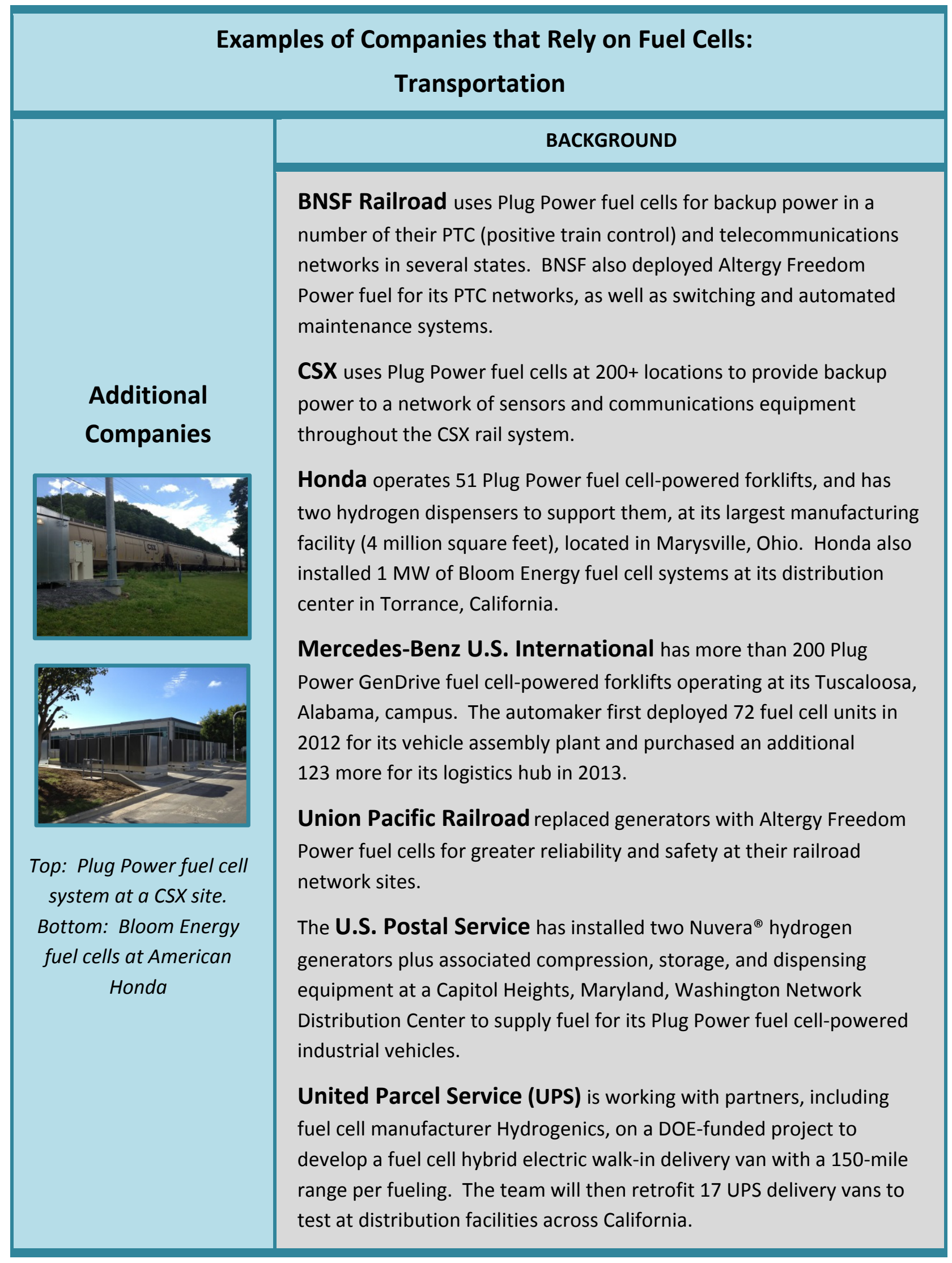




\section{Lighting up Alcatraz Cruises}

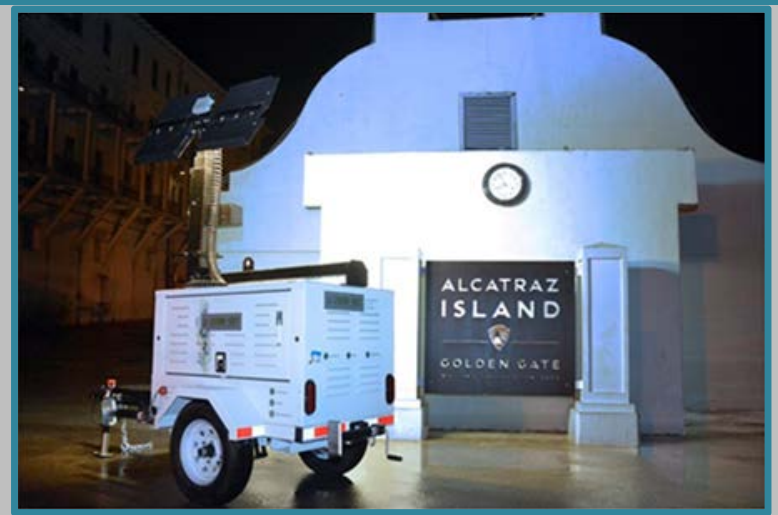

Luxfer-GTM Technologies' Zero-Set Lite, a portable hydrogen fuel cell-powered light tower that uses fuel cells from Plug Power, provided critical working light for an overnight barge exchange operation at Alcatraz Island National Park in San Francisco, California. The operation was part of a planned maintenance period for the Island's embarkation dock, which serves approximately 5,000 visitors per day, and was undertaken by Alcatraz Cruises, official National Park Service concessioner for ferry service to Alcatraz Island.

The Zero-Set Lite was transported by boat across the San Francisco Bay and hoisted by crane onto the Island in order to support the operation. While Alcatraz Cruises crew and subcontractors worked throughout the night in inclement weather, the light tower consistently provided bright, clean, and quiet lighting, allowing crews to see and hear each other clearly in the challenging working conditions.

"Until now it has just been a given that if you needed portable light and power, you were also going to get lots of noise and diesel fumes - and what we found is that that's just not true anymore. The hydrogen fuel cell light tower did a great job of lighting up the work area, and it also made it possible to have a normal conversation in the area with no noise or fumes. The light tower also follows the time-honored maritime K.I.S.S. principle, which stands for: 'Keep It Simple Sailor', in that you can power the unit on and off with the simple push of a button, and there is zero chance

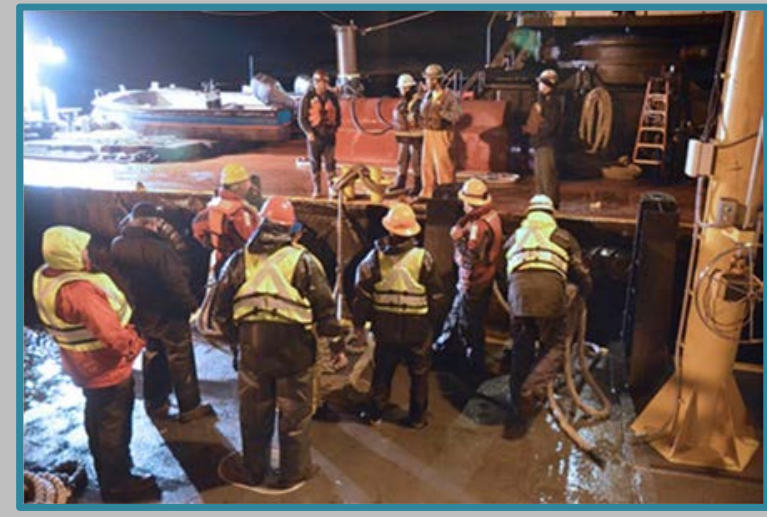
of a fuel spill."

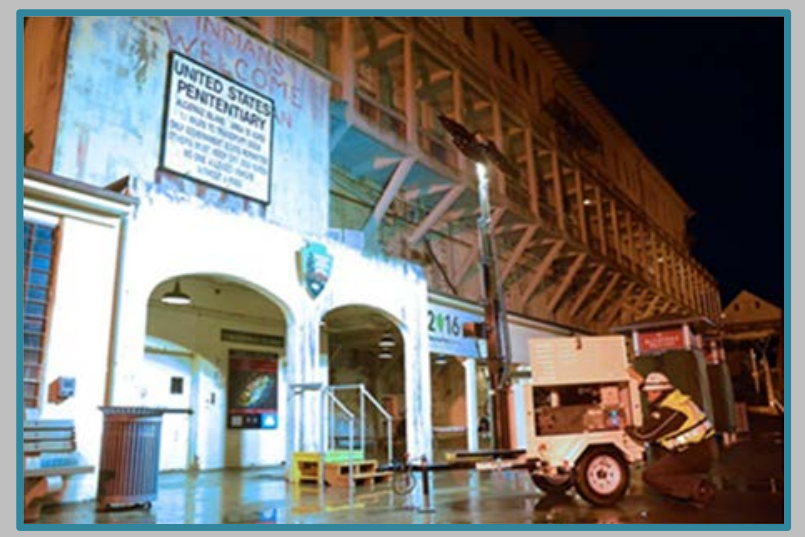

Julian Rose

Special Projects Manager, Hornblower Cruises and events

*images courtesy of Photography by Robert Kaufman 


\section{Utilities}

Electric utility companies are turning to fuel cells, which can be scaled in size from watts to multimegawatts, to generate power for a variety of applications:

- Electricity utilities are using to fuel cells to generate power for the electric grid with fuel cell systems scaled up to $30 \mathrm{MW}$ in size. The world's largest, a $59 \mathrm{MW}$ fuel cell power plant in Korea, could be eclipsed by another planned project in Connecticut that could deliver $63 \mathrm{MW}$ of fuel cell power to the electric grid.

- In the northeast U.S., fuel cells are being selected for micro grid projects to increase power reliability and resilience through storms.

- Utilities also use fuel cells as a backup power supply for radio and supervisory control and data acquisition (SCADA) equipment, power for a natural gas let-down facility, and electricity for customer sites.

In addition, fuel cells and hydrogen are attracting attention for their potential use in energy storage and power-to-gas applications.

\begin{tabular}{|c|c|c|}
\hline \multicolumn{3}{|c|}{$\begin{array}{l}\text { Examples of Companies that Rely on Fuel Cells: } \\
\qquad \text { Utilities }\end{array}$} \\
\hline COMPANY & BACKGROUND & UPDATE \\
\hline Avangrid & $\begin{array}{l}\text { Avangrid, formerly United } \\
\text { Illuminating (UI), has several } \\
\text { FuelCell Energy fuel cell } \\
\text { installations around Connecticut } \\
\text { - a 2.8-MW system at a } \\
\text { Connecticut Natural Gas } \\
\text { Corporation pressure reduction } \\
\text { facility in Glastonbury; a } 2.8 \mathrm{MW} \\
\text { plant located next to existing } \\
\text { substation in New Haven; and a } \\
2.8 \mathrm{MW} \text { plant operating } \\
\text { alongside a solar array in Seaside } \\
\text { Park, Bridgeport. }\end{array}$ & $\begin{array}{l}\text { Avangrid's fuel cell fleet will grow } \\
\text { to } 10 \mathrm{MW} \text { with a } 2.2 \mathrm{MW} \text { fuel cell } \\
\text { to be located at Amity Regional } \\
\text { High School in Woodbridge. The } \\
\text { fuel cell will be the sole power } \\
\text { source of the town microgrid. }\end{array}$ \\
\hline
\end{tabular}




\begin{tabular}{|c|c|c|}
\hline \multicolumn{3}{|c|}{$\begin{array}{l}\text { Examples of Companies that Rely on Fuel Cells: } \\
\qquad \text { Utilities }\end{array}$} \\
\hline $\begin{array}{c}\text { Pacific Gas \& Electric } \\
\text { (PG\&E) }\end{array}$ & $\begin{array}{l}\text { PG\&E, in collaboration with San } \\
\text { Francisco State University, } \\
\text { installed a 200-kW Bloom Energy } \\
\text { fuel cell in } 2011 .\end{array}$ & $\begin{array}{l}\text { PG\&E has also added Altergy } \\
\text { Freedom Power and Plug Power } \\
\text { fuel cells deployed as emergency } \\
\text { backup power units and to } \\
\text { provide backup power to PG\&E's } \\
\text { critical radio and SCADA locations. }\end{array}$ \\
\hline Washington Gas & $\begin{array}{l}\text { Washington Gas has operated a } \\
200-k W \text { Bloom Energy fuel cell } \\
\text { system to provide power at its } \\
\text { headquarters facility in } \\
\text { Springfield, Virginia, since } 2011 \text {. }\end{array}$ & $\begin{array}{l}\text { In September 2016, Washington } \\
\text { Gas reported that it has exceeded } \\
\text { its carbon reduction goals four } \\
\text { years ahead of schedule - and the } \\
\text { fuel cell system played a key role } \\
\text { in this reduction. }{ }^{126}\end{array}$ \\
\hline
\end{tabular}




\section{Examples of Companies that Rely on Fuel Cells:}

Utilities

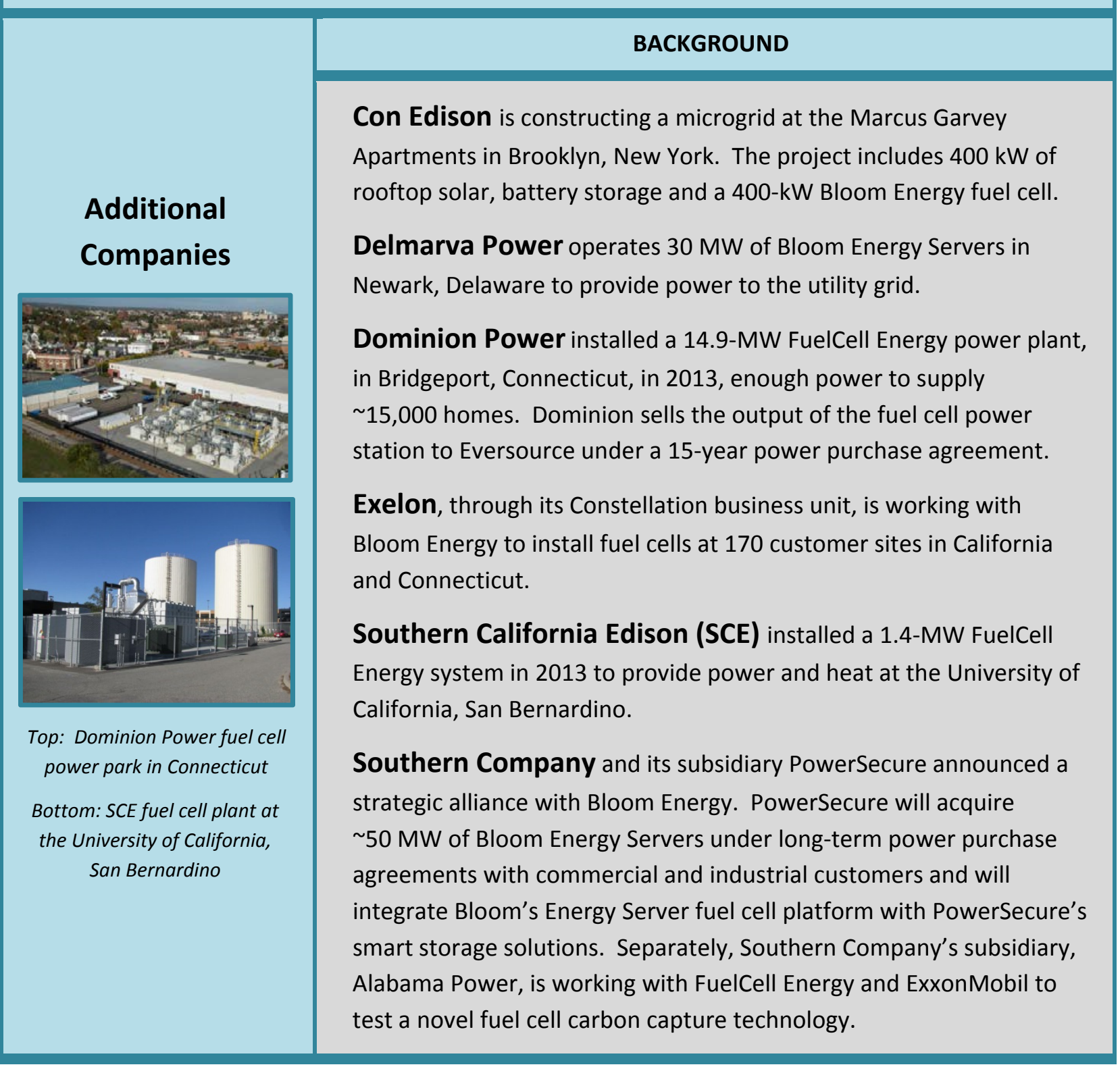




\section{The Growing Business Case for Fuel Cells}

Today fuel cells are contributing to environmental stewardship and helping corporations achieve strategic emissions reduction goals and commitments. Current markets include primary or backup power to facilities or off-grid sites and power supply for MHE. Versatile fuel cells are also beginning to move into other commercial applications.

Oil and gas companies have started using fuel cells to power off-grid equipment; railroads have chosen fuel cells to supply backup power to rail-side equipment, fuel cells are supplying temporary lighting for events, and soldiers use fuel cells to power equipment in the field. Fuel cell vehicles, now available from several major automakers in early global markets, are already operating in taxi and car service fleets in Europe, and, in 2017, the first fuel cell-powered train will debut in Germany.

Several companies are also participating in public-private projects to demonstrate the feasibility and benefits of fuel cells in new applications, such as power for refrigerated containers at port docks (Young Brothers and Sandia National Laboratories), power for airport ground support equipment (FedEx and the Department of Energy), power for aircraft when taxiing (Airbus and the German Aerospace Agency), and as range extenders for battery-powered parcel delivery trucks (FedEx and the Department of Energy).

It is not an overstatement to say that fuel cells have a lot of potential. Stay tuned to the next report for further innovations and for more insight and testimonials on the growing business case for fuel cells. 


\section{Appendix 1: Additional Resources}

For additional technical and industry information on fuel cells and the various applications and markets they serve, please visit:

- DOE's Fuel Cell Technologies Office

- Fuel Cell and Hydrogen Energy Association

Fuel cell and hydrogen companies included in report:

Air Liquide - www.airliquide.com/science-new-energies/hydrogen-energy

Air Products - www.airproducts.com/industries/Energy/Hydrogen-Energy.aspx

Altergy Systems - www.altergy.com

Bloom Energy - www.bloomenergy.com

Doosan Fuel Cell America - www.doosanfuelcell.com

FuelCell Energy - www.fuelcellenergy.com

Hydrogenics - www.hydrogenics.com

Linde - www.the-linde-group.com/en/clean technology/clean technology portfolio/

hydrogen energy $\mathrm{h} 2 /$ index.html

Luxfor-GTM Technologies - www.luxfergtm.com

Millennium Reign Energy - residentialhydrogenpower.com/

Nuvera Fuel Cells - www.nuvera.com

Plug Power - www.plugpower.com 


\section{Appendix 2: Image Credits}

All images were approved for use in this report and were either obtained from a company website or provided directly by the company.

p. 3 - Courtesy of Bloom Energy

p. 4 - Image Courtesy of The Home Depot

p. 5 - Photo courtesy of Bloom Energy

p. 6 - Photo courtesy of Bloom Energy; photo courtesy of Plug Power

p. 8 - Photo Courtesy of Bloom Energy

p. 9 - Photo Courtesy of Air Liquide; photo courtesy of Bloom Energy

p. 10 - Photos courtesy of Bloom Energy

p. 11 - Photo courtesy of Bloom Energy

p. 12 - Photos courtesy of Doosan Fuel Cell America, Inc.

p. 15 - Photo courtesy of FuelCell Energy; chart courtesy of Doosan Fuel Cell America, Inc.

p. 17 - Photo courtesy of Plug Power; photo courtesy of Luxfer-GTM; photo courtesy of Bloom Energy

p. 19 - Photo courtesy of U.S. DOE; photo courtesy of Bloom Energy; photo courtesy of Doosan Fuel Cell America, Inc.

p. 21 - Photos courtesy of Luxfer-GTM

p. 22 - Photos courtesy of Bloom Energy

p. 25 - Photo courtesy of Bloom Energy

p. 26 - Photo courtesy of Bloom Energy; photo courtesy of Plug Power

p. 27 - Photo courtesy of Bloom Energy; photo courtesy of Doosan Fuel Cell America, Inc.

p. 28 - Photos courtesy of Bloom Energy

p. 29 - Photo courtesy of Bloom Energy

p. 31 - Photo courtesy of Bloom Energy; diagram courtesy of Plug Power

p. 32 - Photo courtesy of U.S. DOE

p. 33 - Photo courtesy of Doosan Fuel Cell America, Inc.; photos courtesy of Bloom Energy

p. 34 - Photo courtesy of Bloom Energy

p. 35 - Photo courtesy of Bloom Energy

p. 36 - Photo courtesy of Bloom Energy

p. 37 - Photo courtesy of Doosan Fuel Cell America, Inc.

p. 38 - Photos courtesy of Bloom Energy

p. 39 - Photo courtesy of Bloom Energy

p. 40 - Photo courtesy of Bloom Energy

p. 41 - Photo courtesy of Bloom Energy

p.42 - Photo courtesy of Bloom Energy

p. 43 -Photos courtesy of Bloom Energy; Photo and chart courtesy of Doosan Fuel Cell America, Inc.

p. 44 - Photo courtesy of Bloom Energy

p. 45 - Photo courtesy of FuelCell Energy

p. 46 - Photo and chart courtesy of Doosan Fuel Cell America, Inc. 
p. 47 - Photo courtesy of Doosan Fuel Cell America, Inc.; photo courtesy of Bloom Energy

p. 48 - Photo courtesy of Bloom Energy

p. 49 - Photo courtesy of Bloom Energy

p. 50 - Photo courtesy of Hyatt

p. 51 - Photo courtesy of Plug Power

p. 52 - Photo courtesy of Bloom Energy; courtesy of Plug Power

p. 53 - Photo courtesy of Plug Power; photo courtesy of Bloom Energy

p. 54 - Photos courtesy of Photography by Robert Kaufman

p. 56 - Photo courtesy of Bloom Energy

p. 57 - Photos courtesy of FuelCell Energy 


\section{Appendix 3: Endnotes}

${ }^{1}$ In its 2015 Annual Report, FuelCell Energy states that the levelized cost of energy production from its fuel cells to be $\$ 0.12 / \mathrm{kWh}$ on an unsubsidized basis, with natural gas at $\$ 4.50 \mathrm{MMBtu}$ or $\$ 0.11 / \mathrm{kWh}$ at \$2.50/MMBtu. Source: http://files.shareholder.com/downloads/FCEL/2440061101x0x875451/ 3FE48C03-2C2C-4289-8E03-60BBDB783BAF/FuelCell_AR2015_FINAL.pdf

${ }^{2}$ https://www.eia.gov/electricity/monthly/epm_table_grapher.cfm?t=epmt_5_6_a

${ }^{3}$ http://sciencebasedtargets.org/

${ }^{4}$ http://there100.org/

${ }^{5}$ http://rebuyers.org/

${ }^{6} \mathrm{http}: / /$ www.bcse.org/sustainableenergyfactbook/

${ }^{7}$ http://www.cnbc.com/2016/10/25/home-depot-cut-4800-cars-worth-of-emissions-with-bloomenergy-tech.html

${ }^{8} \mathrm{https}$ ///corporate.homedepot.com/newsroom/fuel-cells-providing-renewable-energy

${ }^{9} \mathrm{http} / / / \mathrm{www}$.newsday.com/long-island/once-disparaged-fuel-cells-are-making-a-comeback-on-longisland-1.11305321

${ }^{10}$ http://www.cnbc.com/2016/10/25/home-depot-cut-4800-cars-worth-of-emissions-with-bloomenergy-tech.html

${ }^{11}$ https://corporate.homedepot.com/newsroom/fuel-cells-providing-renewable-energy

${ }^{12}$ http://seekingalpha.com/article/3963690-plug-power-key-component-home-depots-long-termstrategy-reduce-emissions-electricity-usage

${ }^{13} \mathrm{http}: / /$ www.ikea.com/us/en/about_ikea/newsitem/082216_IKEA_fuel_cell_system_in_New_Haven

${ }^{14}$ http://www.ikea.com/us/en/about_ikea/newsitem/071316-IKEA_increases_fuel_cells

${ }^{15} \mathrm{http}: / /$ www.businesswire.com/news/home/20160823005428/en/IKEA-Grow-Renewable-PortfolioFuel-Cell-System and http://www.businesswire.com/news/home/20160713005230/en/IKEA-IncreaseInvestment-Fuel-Cells-Plans-Systems

${ }^{16}$ Communication with Bloom Energy.

${ }^{17} \mathrm{http}$ ://annualmeeting.naseo.org/Data/Sites/7/media/presentations/Baker.pdf

${ }^{18} \mathrm{http}: / /$ www.bloomberg.com/news/articles/2015-08-12/exelon-s-constellation-doubles-down-onbloom-energy-fuel-cells

${ }^{19}$ http://www.bloomberg.com/news/articles/2015-08-12/exelon-s-constellation-doubles-down-onbloom-energy-fuel-cells

${ }^{20}$ http://corporate.walmart.com/2016grr/enhancing-sustainability/reducing-energy-intensity-andemissions

${ }^{21}$ http://www.thesunchronicle.com/news/local_news/mansfield-looks-to-the-future-ofenergy/article_a5e5f766-3131-5816-bd8e-eab3b9713d88.html

22 https://www.airliquide.com/united-states-america/air-liquide-announces-locations-several-hydrogenfueling-stations-northeast

${ }^{23}$ https://cvshealth.com/sites/default/files/2011-csr-report.pdf

${ }^{24}$ https://corporate.homedepot.com/newsroom/fuel-cells-providing-renewable-energy

${ }^{25} \mathrm{http}: / /$ www.cnbc.com/2016/10/25/home-depot-cut-4800-cars-worth-of-emissions-with-bloom-

energy-tech.html

${ }^{26}$ Communication with Bloom Energy.

${ }^{27}$ http://www.businesswire.com/news/home/20160713005230/en/

${ }^{28} \mathrm{http}: / /$ www.bloomenergy.com/newsroom/press-release-08-23-16/ 
${ }^{29}$ http://cportal.bloomenergy.com/chart/macys/energy/month

${ }^{30} \mathrm{http}: / /$ mde.maryland.gov/marylandgreen/Documents/Staples_Profile.pdf

${ }^{31}$ https://s3-us-west-2.amazonaws.com/wsca-uploads/1420832386_Staples\%20Proposal.pdf

${ }^{32}$ Communication with Bloom Energy.

${ }^{33}$ Communication with Bloom Energy.

${ }^{34}$ Communication with Bloom Energy.

${ }^{35} \mathrm{http}: / /$ www.energymanagertoday.com/walmart-key-goal-of-sustainability-drive-is-to-save-money0117324/

${ }^{36}$ Communication with Bloom Energy.

${ }^{37}$ http://www.foodlogistics.com/article/12199970/cold-storage-operators-gear-up-for-summer

${ }^{38}$ Communication with Bloom Energy.

${ }^{39}$ Communication with Bloom Energy.

${ }^{40} \mathrm{http}: / /$ www.plugpower.com/2016/10/high-five-to-freezpak-food-logistics-2016-top-3pl-cold-storageproviders/?platform=hootsuite

${ }^{41} \mathrm{http}: / /$ sciencebasedtargets.org/wp-content/uploads/2016/06/Case-study_Kellogg_6-6-16.pdf

${ }^{42}$ Communication with Bloom Energy.

${ }^{43}$ http://www.ir.plugpower.com/profiles/investor/ResLibraryView.asp?ResLibraryID=

82090\&GoTopage $=1 \&$ Category $=44 \& B z \mid D=604 \& G=795$

${ }^{44}$ Communication with Bloom Energy.

${ }^{45}$ http://www.ibie2016.com/best-in-baking-program/

${ }^{46}$ Communication with Pepperidge Farm.

${ }^{47}$ Communication with Bloom Energy.

${ }^{48}$ Communication with Bloom Energy.

${ }^{49}$ Communication with Altergy Systems.

${ }^{50}$ http://www.cdn.sierranevada.com/sites/www.sierranevada.com/files/content/sustainability/reports/ SustainabilityReport2015.pdf

${ }^{51}$ http://www.plugpower.com/2016/10/plug-power-gensure-provides-power-hive-for-stone-edge-farmmicro-grid/?platform=hootsuite

${ }^{52}$ Communication with Bloom Energy.

${ }^{53}$ https://www.pge.com/includes/docs/pdfs/mybusiness/energysavingsrebates/incentivesbyindustry/ cs_fuelcells.pdf

${ }^{54}$ Communication with Bloom Energy.

${ }^{55}$ Communication with Bloom Energy.

${ }^{56}$ https://assets.www.bakerhughes.com/system/80/18fc30e27c11e38798db72c1e83be1/GreenhouseGases-Emissions-Reductions-and-Energy-Efficiency-rev1.pdf

${ }^{57}$ http://www.automotiveworld.com/news-releases/bridgestone-ecopia-tires-featured-originalequipment-2016-honda-clarity-fuel-cell-vehicle/

${ }^{58}$ https://mobile.twitter.com/maximintegrated/status/722869964529487872

${ }^{59}$ Communication with Bloom Energy.

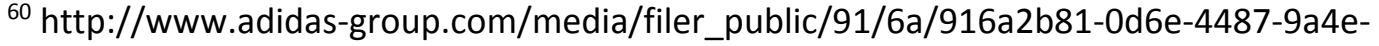

46e9650a0ad3/green_company_performance_analysis_2014.pdf

${ }^{61}$ Communication with Bloom Energy.

62 http://www.adobe.com/content/dam/acom/en/corporate-responsibility/pdfs/adobe-cr-report2015.pdf

${ }^{63}$ Communication with Bloom Energy.

${ }^{64} \mathrm{http}$ ///images.apple.com/environment/pdf/Apple_Environmental_Responsibility_Report_2016.pdf

${ }^{65} \mathrm{http}$ ///about.att.com/content/csr/home/issue-brief-builder/environment/energy-management.html

${ }^{66}$ Communication with Bloom Energy. 
${ }^{67}$ Communication with Bloom Energy.

${ }^{68}$ Communication with Bloom Energy.

${ }^{69}$ Communication with Bloom Energy.

${ }^{70}$ Communication with Bloom Energy.

${ }^{71}$ Communication with Bloom Energy.

${ }^{72}$ https://www.youtube.com/watch?v=B606t1db584

${ }^{73} \mathrm{https}$ ://www.google.com/green/energy/use/

${ }^{74}$ Communication with Bloom Energy.

${ }^{75}$ http://http-download.intuit.com/http.intuit/CMO/intuit/philanthropy/intuit_2011_sustainability_ report.pdf

${ }^{76}$ Communication with Bloom Energy.

${ }^{77}$ https://www.pge.com/includes/docs/pdfs/mybusiness/energysavingsrebates/incentivesbyindustry/ hightech/cs_Juniper.pdf

${ }^{78}$ Communication with Bloom Energy.

${ }^{79}$ Communication with Altergy Systems.

${ }^{80} \mathrm{http} / / /$ www.ir.plugpower.com/profiles/investor/ResLibraryView.asp?ResLibrarylD=

78891\&GoTopage $=7 \&$ Category $=44 \& B z \mid D=604 \& G=795$

${ }^{81}$ Communication with Altergy Systems.

82 http://goodworks.sprint.com/planet/climate/renewable-energy/

${ }^{83}$ Communication with Altergy Systems.

${ }^{84}$ Communication with Doosan Fuel Cell America.

${ }^{85}$ Communication with Bloom Energy.

${ }^{86}$ Communication with Bloom Energy.

87 http://energy.gov/eere/articles/10-facts-know-about-data-centers

${ }^{88} \mathrm{http}: / /$ www.emersonnetworkpower.com/en-US/Resources/Market/Data-Center/Latest-

Thinking/Ponemon/Documents/2016-Cost-of-Data-Center-Outages-FINAL-2.pdf

${ }^{89}$ Communication with Bloom Energy.

${ }^{90}$ Communication with Bloom Energy.

${ }^{91}$ Communication with Bloom Energy.

${ }^{92}$ Communication with Bloom Energy.

${ }^{93}$ http://www.hartfordbusiness.com/article/20160328/PRINTEDITION/303249925/electric-

submetering-rolls-out-in-ct

${ }^{94}$ http://cr.bentallkennedy.com/CaseStudies/EnvironmentCaseStudies

${ }^{95}$ Communication with Bloom Energy.

${ }^{96}$ Communication with Bloom Energy.

${ }^{97}$ http://www.thealhambra.net/innovation/

${ }^{98}$ http://www.medtronic.com/us-en/about/citizenship/further-together.html

${ }^{99} \mathrm{http}: / /$ www.jnj.com/caring/citizenship-sustainability/strategic-framework/Renewable-Use-and-

Development

${ }^{100}$ Communication with Bloom Energy.

${ }^{101}$ Communication with Bloom Energy.

102 http://www.bloomenergy.com/customer-fuel-cell/life-tech-uninterruptible-power/\#!prettyPhoto/0/

103 http://www.medtronic.com/us-en/about/citizenship/further-together.html

${ }^{104}$ Communication with Bloom Energy.

105 Communication with Bloom Energy.

${ }^{106}$ Communication with Bloom Energy.

107 http://doosan.nstig8.com/healthcare/

${ }^{108}$ Communication with Bloom Energy. 
109 http://doosan.nstig8.com/healthcare/

${ }^{110}$ http://www.nfl.com/superbowl/story/0ap1000000134895/article/superdome-power-outage-delayssuper-bowl-xlvii

${ }^{111}$ http://fuelcellseminar.com/wp-content/uploads/sta24-4.pdf

112 https://www.sec.gov/divisions/corpfin/cf-noaction/14a-8/2016/provinceofstjoseph030116-14a8.pdf

${ }^{113}$ Communication with Bloom Energy.

${ }^{114}$ Communication with Bloom Energy.

${ }^{115}$ Communication with Bloom Energy.

${ }^{116} \mathrm{http}: / /$ www.nbcuniversal.com/press-release/nbc-7-san-diego-knsd-unveils-new-state-art-broadcastfacility

${ }^{117}$ Communication with Bloom Energy.

118 http://www.bloomenergy.com/newsroom/press-release-11-19-15/

119 https://www.youtube.com/watch?v=ImTKeO2i7GA\&feature=youtu.be

${ }^{120}$ Communication with Hyatt.

${ }^{121}$ Communication with Bloom Energy.

122 http://www.lindeus.com/en/news_and_media/press_releases/linde-hydrogen-fueling-systemsurpasses-one-million-fills-at-bmw-plant.html

${ }^{123} \mathrm{http}$ ://csr.fedex.com/stories/deliver-it-forward/what-does-a-forester-in-oregon-have-in-commonwith-aircraft-mechanics-students-in-turkey.php

${ }^{124}$ Communication with Bloom Energy.

${ }^{125} \mathrm{https}: / /$ www.youtube.com/watch?v=dDc6W0Qh47U and http://www.plugpower.com/wpcontent/uploads/2015/08/VW-Kassel-Germany.jpg

${ }^{126}$ https://mobile.twitter.com/WGLanswers/status/778997623139229696 and

https://twitter.com/WGLanswers/status/778937282934018048 
This page intentionally left blank. 

Argonne

Argonne National Laboratory

9700 South Cass Avenue

Argonne, IL 60439-4854

www.anl.gov 